\title{
Aetiological agents in occupational asthma
}

\author{
M. Chan-Yeung*, J-L. Malo**
}

Aetiological agents in occupational asthma. M. Chan-Yeung, J-L. Malo. OERS Journals Ltd 1994

ABSTRACT: Occupational asthma has become the most prevalent occupational lung disease in developed countries. At present, about 200 agents have been implicated in causing occupational asthma in the workplace. These agents can be divided into two categories by their mechanism of action: immunological and nonimmunological.

Immunological causes can be further divided into those that induce asthma through an immunoglobulin E (IgE)-dependent mechanism, and those that induce asthma through a non-IgE-dependent mechanism. In the latter category, specific IgE antibodies are found only in a small percentage of the patients with proven disease, even though the clinical picture is compatible with an allergic reaction. The immunological mechanism(s) responsible for these agents has yet to be identified.

The best known example of nonimmunological asthma is Reactive Airways Dysfunction Syndrome (RADS) or irritant-induced asthma.

In this review, examples of types of agents causing occupational asthma are discussed and a compendium table of aetiological agents is given.

Eur Respir J., 1994, 7, 346-371.
*Dept of Medicine, Vancouver General Hospital, Vancouver, Canada. **Dept of Chest Medicine, Hôpital du Sacré-Coeur, Montreal, Canada.

Correspondence: J-L. Malo, Dept of Chest Medicine, Hôpital du Sacré-Coeur, 5400 West Gouin, Montreal, H4J ICS, Canada.

Keywords: Asthma occupational asthma

Received: July 161993

JL Malo and M Chan-Yeung are members of the Canadian Network of Excellence in Respiratory Health.
The prevalence of occupational asthma has increased over the past two decades $[1,2]$. This due partly to a better recognition of the condition, and partly to an increase in the number of new chemicals capable of causing occupational asthma in the workplace. At present, nearly 200 agents have been implicated in causing occupational asthma in the workplace [3].

\section{Definition of occupational asthma}

In this article, occupational asthma is defined as recommended by BERNSTEIN et al. [4]. It is a disease characterized by variable airflow limitation and/or nonspecific bronchial hyperresponsiveness (NSBH) due to causes and conditions which are attributable to a particular occupational environment and not to stimuli encountered outside the workplace. Occupational asthma may encompass both immunological and nonimmunological causes 1) immunological occupational asthma occurs upon exposure to an agent after a latent period of immune sensitization; 2) nonimmunological asthma may or may not occur after a latency period of exposure to an agent(s) which does not induce immune sensitization as determined by currently available technology

Under certain exposure conditions, immunological and nonimmunological asthma may be concurrent.

\section{Aetiological agents in occupational asthma}

The aetiological causes of occupational asthma can be classified into immunological and nonimmunological. Immunological causes can be further divided into those that induce asthma through an immunoglobulin $\mathrm{E}(\mathrm{IgE})$ dependent mechanism, and those that induce asthma through a non-IgE-dependent mechanism. In the latter category, specific IgE antibodies are found in only a small percentage of the patients with proven disease, even though the clinical picture is compatible with an allergic reaction. The immunological mechanism has yet to be identified. As it is not possible to cover all aetiological causes in this article because of limited space, only the most commonly encountered and most studied causes will be discussed.

\section{Agents causing asthma through immunological mechanisms}

Occupational asthma due to immunological causes has the following characteristics that distinguish it from occupational asthma due to nonimmunological causes: 1) there is a latent period between the onset of exposure and the onset of respiratory symptoms; and 2) in sensitized subjects, re-exposure to a small amount of the causative agent leads to the occurrence of asthma.

\section{IgE-dependent causes}

It has been demonstrated for many years that agents inducing asthma through an IgE-dependent mechanism are high molecular weight proteins or polysaccharides. Recently, several low molecular weight compounds have been shown to produce specific IgE antibodies, by 
combining with a protein to form a hapten-protein conjugate [5]. There is good evidence to suggest that specific IgE antibodies to the hapten-protein conjugate are responsible for the patients' symptoms. Occupational asthma due to IgE-dependent aetiological agents mostly affects atopic subjects. In sensitized subjects with symptoms, specific inhalation challenge tests with extracts of these agents induced isolated immediate asthmatic reaction or a biphasic asthmatic reaction, but rarely an isolated late asthmatic reaction. Smoking has been shown by some to be an important determinant of some types of occupational asthma but not others [6]. Table 1 in the Appendix shows some of the IgE-dependent causes of occupational asthma, according to industries, jobs or work processes where the exposure can be found.

\section{High Molecular weight compounds (table)}

\section{Animal products}

Laboratory animal allergens. Exposure to laboratory animals occurs in the pharmaceutical industry, in university and research units, and in animal breeding facilities. Small animals are often used in these places. The most common cause of asthma is rats, followed by mice, and rabbits. The allergens are usually found in the excreta and the secreta of these animals [7]. In rats and mice, the major source of allergen is in the alpha $a_{2}$-globulin and/or the prealbumin portion of the protein in urine [7]. The allergenic protein appears in the urine of male rats after puberty and disappears with senility. In guineapigs, allergens have been identified in the urine, serum, saliva and pelt. Again the allergenic activity is highest in the prealbumin region. The nature and the sources of rabbit allergens have been less extensively studied.

The prevalence of asthma due to laboratory animal allergy is not know. In the United Kingdom, the Surveillance of Work-Related and Occupational Respiratory Disease (SWORD) project group [1] reported an estimated incidence of 204 cases of occupational asthma per million animal handlers per year. About one third of the animal handlers have allergic symptoms, such as allergic rhinitis and contact urticaria; whilst $10 \%$ have symptoms of asthma. The results of a longitudinal study of workers in the pharmaceutical industry were reported by Вотнам et al. [8]. The prevalence of specific IgE antibodies to rat urine proteins was $28 \%$ during the first year of employment, $37 \%$ in the subsequent two years, but fell to around $10 \%$ in the fifth to seventh year [8]. The improvement was attributed to improved work practice and the use of personal protection rather than to selection.

Clinically, allergic symptoms develop within the first 2-3 yrs of exposure. A recent study of patients with different types of occupational asthma showed that the latency period between the onset of exposure and the onset of symptoms is longer for patients with asthma due to high molecular weight compounds than for those with asthma due to low molecular weight compounds [9].
Asthma usually occurs several months after the development of other symptoms. Atopic animal handlers are more prone to develop asthma [10].

The diagnosis of occupational asthma in laboratory animal handlers is based on the presence of a compatible history, with objective evidence of work relationship and evidence of sensitization. Objective evidence of work relationship can be obtained by peak expiratory flow rate (PEFR) monitoring for a period at work and a period off-work, or by a specific inhalation challenge test with appropriate extracts if available. Evidence of sensitization can also be obtained by a positive skin test or presence of specific $\operatorname{IgE}$ antibodies with the appropriate extracts.

One of the important technological advances in occupational asthma is the ability to measure the amount of airborne allergens [11]. This enabled investigators to study factors that determine the levels of allergens in animal laboratories and methods of reducing these allergens [12-14]. The latter includes the reduction of stock density, the use of female rats rather than male rats, the use of corn cob rather than wood shaving as bedding, and covering of the cages with filter caps [13].

Other animal-derived allergens. Other animal-derived proteins have been incriminated as causing occupational asthma. Asthma caused by exposure to pig-derived allergens in a meat factory has been described [15]. Handling of bovine serum albumin powder caused occupational asthma in a laboratory technician [16]. Exposure to egg proteins has been reported to cause occupational asthma [17]. In a survey of 188 workers employed in a factory that produced liquid and powdered egg products, $7 \%$ were found to have physician-diagnosed asthma and evidence of sensitization to one or more egg proteins [18].

Different types of insects can give rise to occupational asthma. Storage mites have been incriminated as allergens for occupational asthma among farmers [19, 20]. Other types of mites such as spider mites and poultry mites have been found to be the cause of occupational asthma in greenhouse workers and poultry workers, respectively, [21, 22]. Laboratory workers breeding insects such as grain weevil [23], locust [24, 25] and fruit fly [26], are at risk of developing occupational asthma.

\section{Plant proteins of polysaccharides}

Flour. In some countries, baker's asthma is the most prevalent type of occupational asthma [27]. The majority of patients with baker's asthma are allergic to wheat and rye flour. There is considerable cross-reactivity between antigens in wheat and rye flour and those in other cereals, such as barley and triticale, but less to oats, corn and rice [28]. Crossed immunoelectrophoresis studies of wheat extract identified 40 different allergens [29]. However, the major allergens are found in globulin, gliadin and glutenin fractions [30].

Several other non-cereal antigens have been identified as capable of causing asthma in bakers. Sensitization to 
Aspergillus and Alternaria has been implicated in two bakers with asthma [31]. Other food additives such as alpha-amylase, hemicellulase and papain, used as enzymes in bakeries, can also cause sensitization [32, 33].

It has been estimated that about $10-20 \%$ of bakers suffer from baker's asthma [27]. A cross-sectional study of 318 bakers showed that $13 \%$ had respiratory work-related symptoms [34]. The degree of nonspecific bronchial hyperresponsiveness (NSBH), lung function level, and skin test reactivity to antigens tested correlated with the current level of flour dust exposure and the estimated total exposure.

The onset of asthma in bakers is usually preceded by nasal symptoms, such as sneezing, rhinorrhoea and itchy eyes. The latent period between the onset of exposure and the onset of respiratory symptoms varies between a few months and a few years [35]. Almost all patients are atopic subjects with skin reactivity to common allergens. The diagnosis of baker's asthma is usually based on a compatible clinical history, presence of airflow limitation and/or presence of NSBH, or the demonstration of positive skin test to the appropriate flour extract. Positive bronchial reactions to flour extract occurred in symptomatic workers in association with high specific IgE level and a higher degree of NSBH [36].

Workers exposed to grain dust such as grain elevator terminal workers and farmers do not, as a rule, become sensitized to cereal flours but to other components in the grain dust. For example, occupational asthma in grain farmers is usually related to sensitization to storage mites such as Glycyphagus destructor [37].

Pharmaceutical products. Some pharmaceutical products are proteins, such a ipecacuanha, derived from the roots of Cephaelis ipecacuanha, or polysaccharides, such as psyllium.

Occupational asthma due to psyllium has been studied more extensively than other proteinaceous pharmace utical products [38]. The clinical picture of psylliuminduced asthma is well-documented in several case reports [39-44]. In addition to asthma, many patients also complained of ocular and nasal symptoms [45]. Specific IgE antibodies to psyllium have been found in these patients. The prevalence of sensitization among pharmaceutical workers was between $28 \%$ [46] and 44\% [47]; whilst the prevalence of occupational asthma confirmed by specific challenge test was 4\% [46]. Among nurses working in long-term care facilities, the prevalence of positive skin test was lower $(5 \%)$, but the prevalence of confirmed occupational asthma by specific challenge test was also $4 \%$ [38].

Gums. Gums are derived from plants and are high polymer carbohydrates that produce mucilages when they react with water. Common examples include acacia or arabic gum, used in the food and pharmaceutical industries; tragacanth, used mainly in printing; karaya, which grows in India, and can be used instead of tragacanth. Guar gum, another natural gum, was reported to be responsible for asthma in the carpet-manufacturing industry [48]. Occupational asthma due to acacia gum was described as early as 1933 [49]. Later, cases of asthma among printers exposed to acacia gums were documented [50]. Five percent of workers in a carpet-manufacturing factory was found to have positive skin tests to guar gum, while $2 \%$ had occupational asthma diagnosed by specific challenge tests [48].

\section{Enzymes}

Detergent enzymes. Proteolytic enzymes from Bacillus subtilis were introduced in detergent products in the 1960s. Within a few years of their introduction, several investigators reported the association of exposure to detergent enzymes with asthma, nasal and ocular symptoms among workers involved in the manufacture of detergents [51,52]. These workers showed positive skin test reactivity to $B$. subtilis alcalase and developed an immediate or late asthmatic reaction on inhalation challenge [53]. A fall in diffusing capacity was found in some workers following inhalation challenge test, suggesting involvement of lung parenchyma as well as airways [52]. An epidemiological study of detergent manufacturing workers demonstrated that $21 \%$ had skin sensitivity to alcalase; of these, $66 \%$ were atopic subjects [54]. Reports of sensitization in consumers followed later. Four percent of 461 individuals attending an allergy clinic with no known occupational exposure to detergent enzymes had positive skin test to alcalase [53]. Positive nasal or bronchial reactions to challenge with the enzyme were documented in some of the consumers [53].

Since these reports, measures were taken to reduce exposure not only for workers but also consumers. Ventilation was improved in factories, and changes were made in manufacturing processes, such as enclosing the purification of enzymes. These enzymes were also glued to phosphate granules to prevent them from getting dispersed, or were encapsulated. Despite the substantial reduction in levels, a study showed that sensitization still occurred in $25 \%$ of workers [55]. However, in a study of the general population, no sensitization to alcalase was found, indicating that the use of enzymes in granules and encapsulation had been successful, at least in eradicating the disease among consumers [56].

Other enzymes. Both plant-derived enzymes, such as papain from papaya and bromelin from pineapple, and animal-derived enzymes, such as hog trypsin, are frequently used in the food industries. Some of them have been found to cause occupational asthma [57].

\section{Fish and seafood protein}

Processing of several types of seafood can cause occupational asthma. Oyster handlers were found to be sensitized to the "hoya" or "sea-squirt" contaminating oysters, and developed symptoms of rhinitis and asthma [58]. Oysters themselves were not the source of allergen. Processing of prawns gave rise to asthma in 18 out of 50 workers [59]. Inhalation challenge test with the 
prawn extract on two volunteers induced isolated late asthmatic reaction in one and dual asthmatic reaction in the other [59].

Occupational asthma associated with snow crab processing has been studied in detail [60]. During the process of boiling, a vapour is released from the snow crab. Inhalation of the vapour containing proteins from snow crabs resulted in sensitization of workers. In a study of two snow crab processing plants along the St. Lawrence River with 313 employees, 33 were confirmed to have occupational asthma by specific challenge tests [60].

\section{Low molecular weight compounds (table 1)}

Some low molecular weight compounds have been shown to cause occupational asthma associated with the production of specific IgE antibodies against the haptenprotein conjugates. The most well known compounds in this group include acid anhydrides, metals such as platinum and some pharmaceutical products.

\section{Acid anhydrides}

There are several acid anhydrides: phthalic anhydride, trimellitic anhydride, hexahydrophthalic anhydride, himic anhydride and tetrachlorophthalic anhydride. These anhydrides are used in alkyd and epoxy resins. Alkyd resins form the base for paints, varnishes and plastics. Epoxy resins are widely-used in adhesives, casting, coating, and sealants. Trimellitic anhydrides are mainly used as plasticizers for polyvinyl chloride, especially when temperature stability is required. Acid anhydrides can give rise to hypersensitivity reactions in exposed population. They act as haptens and combine with proteins to form conjugates with antibodies recognizing the haptens [61]. They can also combine with self-proteins to generate new, carrier-dependent antigenic determinants with antibody combining sites being directed against a conformational change in the self-proteins [61].

Phthalic anhydride. Since 1939, phthalic anhydride has been known to cause asthma and rhinitis [62]. Specific $\mathrm{IgE}$ antibodies to phthalic anhydride conjugated to human serum albumin have been demonstrated [63].

Trimellitic anhydride. Trimellitic anhydride induced not only specific immunoglobulin $\mathrm{E}, \mathrm{A}, \mathrm{M}$ and $\mathrm{G}(\operatorname{IgE}, \operatorname{Ig} \mathrm{A}$, $\operatorname{IgM}$ and $\mathrm{IgG}$ ) antibodies against the hapten but also to the new antigenic determinants that arise when trimellitic anhydride couples with proteins [61]. Trimellitic anhydride has been shown to cause a spectrum of lung diseases: asthma and rhinitis, late respiratory systemic syndrome and pulmonary disease-anaemia syndrome [64]. Whilst IgE antibodies are probably responsible for asthma, connections have been made between other antibodies and late respiratory systemic syndrome and pulmonary disease-anaemia syndrome [65]. A study was conducted on 474 employees exposed to trimellitic anhy- dride. Evidence of trimellitic anhydride immunological lung disease was observed in $6.8 \%$ [66]. A direct relationship was found between the levels of total and IgE antibodies and the degree of exposure.

Tetrachlorophthalate anhydride. In a survey of 276 workers exposed to tetrachlorophthalate anhydride (TCPA), specific IgE antibodies to the TCPA-conjugate were found in $12 \%$ of atopic subjects and $6 \%$ of nonatopic subjects. There was a strong interaction between smoking and atopy; smokers who were atopic subjects had the highest prevalence of positive specific IgE antibodies [67]. A follow-up study of workers with TCPA-induced asthma showed a progressive reduction in levels of specific IgE antibodies after removal from exposure. The halflife of these antibodies was one year [68]. Various animals: rats, Rhesus monkeys, dogs, rabbits and guinea-pigs have been used, without success, to induce a model of IgE-mediated airway disease to anhydrides [61]. Although other types of hypersensitivity reactions were induced, airway hyperresponsiveness was not found.

Metals

In addition to asthma, inhalation of metallic compounds can give rise to chemical pneumonitis, bronchitis and metal fume fever. Chronic exposure has been associated with chronic bronchitis, emphysema and, in the case of hard metals, pneumoconiosis.

Exposure to metals may occur not only in metal mining and metallurgical industries, but in a number of other trades, such as welding and soldering. Chromates are found in paints, chemical and plastic industries, while cobalt is found in diamond polishing discs [69]. Metals that can induce asthma can be divided into three categories: 1) transition metals, such as vanadium, chromium, nickel and zinc; 2) precious metals, such as platinum and palladium; and 3) hard metals, such as tungsten carbide and cobalt.

Nickel. Exposure to nickel occurs during mining, milling, smelting, and refining processes, as well as in electroplating industries and in the production of nickel catalysts. The occurrence of nickel-induced asthma among exposed workers is rare compared to contact dermatitis. In the literature, there have been several case reports of nickel-induced asthma associated with exposure to nickel sulphate; some confirmed by inhalation challenge tests $[70,71]$. Specific IgE antibodies to nickel-human serum albumin conjugate have been reported in some cases [70]. Recently, lymphocyte transformation was demonstrated in patients with nickel-induced asthma, suggesting that cell-mediated hypersensitivity may play a part in nickelinduced asthma [72].

Chromium. Chromium metal is nonallergenic. Chromium salts are well-known to give rise to contact dermatitis. Exposure to chromium salts occurs in electroplating, tanning, pigment and cement production. The development of asthma is frequently preceded by a history of 
contact dermatitis. As in nickel-induced asthma, cellmediated hypersensitivity may be important.

Platinum. Platinum salts, particularly halides, are more potent in inducing asthma than other metallic salts. Exposure to platinum occurs in mining, in primary and secondary refining processes, and in chemical industries where platinum is used as a catalyst. During the refining process, hydrochloric acid and chlorine are added. It is the halide salts that give platinum its allergenicity. Platinum-induced asthma has been recognized for a long time [73, 74]. Positive skin tests with the appropriate platinum salts (unconjugated) were found in sensitized workers [75]. Specific IgE antibodies were detected by radio allergosorbent test (RAST) procedures [76]. A Type I allergic reaction is likely to be responsible for the pathogenesis of platinum salt-induced asthma.

In a recent cross-sectional study of a secondary refinery, $14 \%$ of the 107 current employees and $28 \%$ of the 29 workers laid-off for medical reasons had positive skin test reactivity to platinum salts, suggesting that the current employees were "healthier". In this study, the prevalence of atopy was similar among those with positive and negative skin tests to platinum salts, and those of the general population, suggesting that atopy is not an important determinant. However, smoking was found to be strongly associated with sensitization to platinum salts [77].

Zinc. Exposure to zinc occurs in the steel manufacturing industry, where it is used as an alloy. It is also used as a component of brass, and in the insecticide industry. The most important exposure to zinc occurs in welding of galvanized iron. Exposure to fumes of zinc oxide is associated with metal fume fever, which is a flu-like illness, sometimes associated with cough and shortness of breath. Several cases of occupational asthma have been described related to exposure to fumes of zinc oxide [78, 79].

\section{Other}

There are other low molecular weight compounds that can act as haptens and cause asthma by inducing specific IgE antibodies. It is not possible to discuss all of them here.

\section{Non-IgE-dependent causes}

The majority of low molecular weight compounds induce asthma by mechanisms as yet unidentified, as specific IgE antibodies to the offending agents have not been found, or found in only a small proportion of patients with the disease. The clinical picture of these patients is compatible with that of an allergic disease. The accompanying table shows some of these causes. Specific challenge tests with these agents commonly induce late asthmatic reactions, either as an isolated asthmatic reaction or as the late component of biphasic reactions, and in some cases reactions that are atypical [80]. The majority of affected subjects are nonatopic and nonsmokers [81]. Thus, these non-IgE-dependent agents are different from other types of low molecular weight compounds that induce specific IgE antibody production. Asthma due to diisocyanates and asthma due to the Western red cedar are examples of non-IgE-dependent causes that have been studied in detail and will be discussed here.

\section{Diisocyantes}

Occupational asthma due to diisocyanates has been reviewed in detail by VANDENPLAS et al. [82]. Diisocyanates are being used extensively in a number of important industries all over the world. They are a group of small molecular weight cyclic or linear organic chemical compounds, synthesized by the reaction of amines or their hydrochlorides with phosgene. These chemicals all have an $-\mathrm{N}=\mathrm{C}=\mathrm{O}$ group attached to a radical, and react exothermically with compounds containing active hydrogen atoms, such as polygycols, to form a polymeric mass, polyurethane (fig. 1). Monomers of isocyanates can exist in aromatic, aliphatic or cycloaliphatic forms (fig. 2). Prepolymers of isocyanates have also been shown to give rise to occupational asthma [82]. Toluene diisocyanate (TDI) was first developed during the second World War and is the most commonly used diisocyanate. Since that time, other isocyanates have been developed, such as methylene diphenyl diisocyanate (MDI), hexamethylene diisocyanate (HDI), naphthylene diisocyanate (NDI), and isophorone diisocyanate (IPDI). They are used in the production of rigid and flexible foams, as protective coatings for electric wiring, for painting automobiles, as adhesives and binders in foundries, as liners for mine and grain elevator chutes, soles of shoes and spandex fibres. Thus, they have a wide application in both industrial and domestic use.

Toluene diisocyanate. TDI-induced asthma has been the most common cause of occupational asthma in many parts of the world for many years. However, in recent years, it has been replaced by HDI and MDI [82]. The prevalence of TDI-induced asthma varies from 5 to $10 \%$, depending on the type of industry, the type of diisocyanate, and the level of exposure [82]. Many cases of TDI-induced asthma occurred after a high level of exposure, e.g., a spill [83]. In those situations, a Reactive Airways

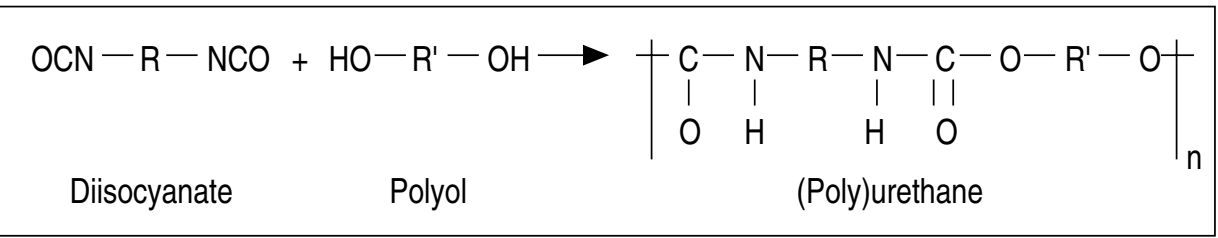

Fig. 1. - $-\mathrm{N}=\mathrm{C}=\mathrm{O}$ ) group attached to a radical, reacts with compounds containing active hydrogen atoms, such as polyglycols, to form a polymeric mass, polyurethane. 
Aromatic radical

Toluene diisocyanate (TDI)<smiles></smiles><smiles></smiles>

2,4'-MDI

Methylene diphenyl diisocynate (MDI) 1,5-naphthylene diisocyanate (NDI)<smiles>O=[N+]([O-])c1cccc2c([N+](=O)[O-])cccc12</smiles>

\section{Aliphatic radical}

Hexamethylene diisocyanate (HDI)

$$
\mathrm{OCN}-\left(\mathrm{CH}_{2}\right)_{6}-\mathrm{NCO}
$$

\section{Cycloaliphatic radical}

Isophorone diisocyanate (IPDI)<smiles>CC1(C)CC(CN=O)CC(C)(CN=O)C1</smiles>

4,4'-dicyclohexylmethane diisocyanate (hydrogenated MDI, HMDI)

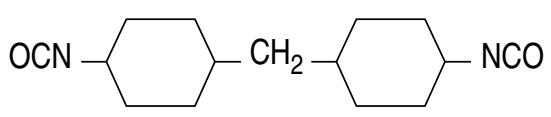

Fig. 2. - Structure of different monomers of isocyanates.

Dysfunction Syndrome (RADS)-type of occupational asthma could not be excluded. Recently, there has been a report that certain genetic factors related to human leucocyte antigen (HLA) Class II may convey protection, whilst others convey susceptibility [84]. Obviously, a great deal of work needs to be done in this area.

The dose and length of exposure to TDI which will induce asthma are not known. Recommendations from the National Institute for Occupational Safety and Health (NIOSH) are that humans should not be exposed to concentrations above $20 \mathrm{ppb}$ [85]. Several animal models have been developed to study TDI hypersensitivity reaction. In guinea pigs, specific $\operatorname{IgG}_{1}$ and not $\mathrm{IgE}$ antibodies were found; in another study, specific IgE antibodies were detected $[86,87]$. Irrespective of whether antibodies were present or not, the animals developed airflow obstruction and NSBH. The uptake and distribution of TDI have also been studied in guinea-pigs [88, 89]. Most of the TDI was absorbed in the upper airways; the uptake, as reflected by the concentration of ${ }^{14} \mathrm{C}$ in the blood, correlated with the concentration in inhaled air. In the airways, labelled TDI was found in the epithelium and subepithelium from the nose to terminal bronchioles but not in the alveoli [88, 89]. In the blood, the labelled TDI was found in the plasma, conjugated to a $70,000 \mathrm{kD}$ a molecular weight protein. In the airways, TDI was also found conjugated with a 70,000 $\mathrm{kD}$ a molecular weight protein, which was shown to be laminin. These studies may be helpful for the identification of the protein conjugated to isocyanates in humans.

Clinically, once a subject has been sensitized to TDI, very low levels of TDI (as low as $1 \mathrm{ppb}$ ) may trigger an attack of asthma. Specific challenge tests with TDIinduced isolated immediate, isolated late, biphasic or a continuous reaction in sensitive subjects. Recurrent late asthmatic reaction has been reported after one single challenge to TDI [90]. The development of late asthmatic reaction has been shown to be accompanied by the development of NSBH in about $60 \%$ of subjects [80]. Once asthma has developed, the majority had persistence of symptoms even after they were removed from exposure [91-94]. Favourable prognostic factors include early diagnosis and early removal from exposure. The mechanism of TDI-induced asthma is not known. Specific IgE antibodies to a protein conjugate of TDI or a monoisocyanate were present in only a small proportion (10-20\%) of patients who were shown to have specific asthmatic reactions on inhalation challenge test. Skin prick testing with hapten-protein conjugates has been negative [95]. There have been reports indicating that the immune response could be directed against neoantigens formed by the reaction of TDI with body proteins [96], as in other highly reactive low molecular weight compounds [97]. Specific lymphocyte blastogenic activity and lymphokine leucocyte inhibitory factor responses to TDI have been detected in sensitive workers, and suggest that cell-mediated hypersensitivity reaction may play a part [96]. TDI has several other effects that might induce NSBH or potentiate sensitizing properties. It has been shown to have beta-adrenergic blockade properties [98], to stimulate the release of neuropeptides and to inhibit neutral endopeptidases in in vivo and in vitro studies [99].

Irrespective of the mechanism of induction of asthma, airway inflammation was found in patients with TDIinduced asthma both by bronchoalveolar lavage (BAL) and bronchial biopsy studies [99]. The pathology of the lungs of a patient with isocyanate-induced asthma who died during an attack showed similar findings as those 
who died from status asthmaticus [100]. The airways were plugged with mucus. There was sloughing of the epithelium and marked cellular infiltration of neutrophils and eosinophils. The basement membrane was thickened and the smooth muscle hypertrophied. The pathology of the airways of patients with TDI asthma was studied before and after exposure ceased. The thickening of the basement membrane observed when the patients were still exposed and symptomatic became less severe, suggesting this change was partly reversible [99].

\section{Methylene diphenyl diisocyanate (MDI)}

Methylene diphenyl diisocyanate is used in the production of rigid foam, and as a binder in almost all mould and core processes in iron and steel foundries. At room temperature, MDI is a solid. It has to be heated above $60^{\circ} \mathrm{C}$ before vapours are given off. The health effects of MDI exposure are less well-studied than TDI. Both occupational asthma and hypersensitivity pneumonitis and a combination of both have been described [82]. The prevalence of these diseases among exposed workers is not known. In one study of 78 workers in an iron and steel foundry utilizing MDI as a binder, the prevalence of cough, wheeze and chest tightness associated with NSBH was $18 \%$ [101]. A specific challenge test with MDI on 11 of the workers showed that six had a specific asthmatic reaction, two had a dual reaction, and four had an isolated late reaction. Four out of the six workers had recurrent nocturnal asthmatic reaction after one challenge test. Both specific IgE and specific IgG antibodies to MDI-HSA conjugate were detected in workers exposed to MDI. The relationship between the clinical disease and the presence of antibodies is not clear in MDI-induced asthma. At this stage, the presence of antibodies should indicate the presence of sensitization and not necessarily disease. In MDI lnduced hypersensitivity pneumonitis, however, specific IgE or IgG antibodies are usually present [102].

Hexamethylene diisocyanate (HDI). Hexamethylene diisocyanate is more volatile than TDI but it is used extensively in automobile and aircraft spray paints to produce finishing coatings. Cases of occupational asthma due to HDI exposure have been reported in the literature [82]. A prospective study was carried out on 150 workers exposed to HDI and its trimer during an 18 month period [103]. Specific IgE and IgG antibodies to a protein conjugate were detected in $21 \%$ of the workers. The presence of antibodies was not associated with the presence of clinical disease. However, the duration of follow-up was short, and it was not possible to draw any firm conclusions.

\section{Western red cedar}

Occupational asthma due to Western red cedar dust exposure is the most common type of occupational asthma in the Pacific Northwest. In British Columbia, Canada, it accounts for $70 \%$ of all the compensation claims for occupational asthma (Chan-Yeung M, unpublished observation). Western red cedar is used extensively for both indoor and outdoor construction, because of the durability. It is different from other wood in its high content of chemicals in the wood. Plicatic acid (PA) is one of the chemicals present uniquely in this wood and it has been found to be responsible for red cedar asthma [104]. Its structural formula is shown in figure 3. It has a molecular weight of $440 \mathrm{Da}$.

Red cedar asthma affects $4-14 \%$ of the exposed population, depending on the type of industry and the level of dust exposure [105]. There is a good correlation between the dust level and the prevalence of work-related asthma in exposed workers [106, 107]. The higher the dust concentration, the higher the prevalence of work-related asthma. As in TDI-induced asthma, the patients are mostly nonatopic subjects and nonsmokers. Recently, a follow up study of workers in a cedar sawmill showed that NSBH only developed in parallel with the development of red cedar asthma, indicating that NSBH is not a predisposing host factor [108].

The clinical feature of red cedar asthma is similar to TDI-induced asthma. There is a latent period between the onset of exposure and the onset of symptoms. At the onset of the disease, the patients usually complain of cough, wheeze, and shortness of breath at the end of the workshift. Later, with continual exposure, the patients complain of symptoms immediately they are exposed to the wood dust. In the first stages of illness, there is a remission of symptoms during weekends and holidays. Later on, there is no remission of symptoms. Inhalation challenge test with an extract of Western red cedar or plicatic acid induce the same types of asthmatic reactions as patients with TDI. Systemic reaction or alveolar reaction has not been observed.

Follow-up studies of patients with red cedar asthma showed that about $60 \%$ of patients failed to recover several years after they were removed from exposure [105]. Those who recovered, tended to be diagnosed early and removed from exposure early. They had normal lung function and a lower degree of NSBH at the time of diagnosis compared to those who failed to recover. For those who had to remain in the same job, persistent asthma was the rule. The use of respirators and the reduction of exposure by a change to a less dusty job did not improve the prognosis [109].

The pathogenic mechanism of asthma induced by PA is not clear. Skin tests with extracts of red cedar and PA have been negative in patients with proven disease [104]. Plicatic acid can be conjugated to human serum albumin (HSA) to form an allergen. Using this conjugate as antigen, specific IgE antibodies can be found by radioallergosorbent tests (RASTs) method in about $20 \%$ of patients proven by inhalation challenge [110]. Bronchoalveolar lavage studies of patients before and during immediate asthmatic reaction showed a release of inflammatory mediators, including histamine, prostaglandin $\mathrm{D}_{2}$, leukotriene $\mathrm{E}_{4}$ and thromboxane $\mathrm{B}_{2}$ into the $\mathrm{BAL}$ fluid [111]. During the late reaction, an increase in eosinophils and albumin was found, together with sloughing of the epithelium [112]. Bronchial biopsy performed during 
<smiles>COc1cc2c(cc1O)C(c1cc(O)c(O)c(OC)c1)C(O)(C(=O)O)C(O)(CO)C2</smiles>

Fig. 3. - Structure of plicatic acid.

the late reaction showed similar findings to patients with allergen-induced asthma [112]. These findings suggest that there might be low levels of specific IgE antibodies to PA-HSA conjugate, not detectable by the RAST method.

To test the above possibility, serum from patients with red cedar asthma was used to passively sensitize human lung fragments, and the fragments were then challenged with PA. No release of histamine was found, even though, under the same conditions, the lung fragments released histamine when passively sensitized and then challenged with grass pollen extract [113]. Basophils from patients with red cedar asthma were found to release histamine on direct challenge with PA. There was no inhibition of release of histamine when the basophils were previously desensitized by incubation with anti-IgE, while this desensitizing protocol reduced the responsiveness of basophils from atopic subjects to a challenge with grass pollen or with anti-IgE. These findings confirmed that specific IgE antibodies cannot be responsible for the release of histamine in patients with red cedar asthma. Further studies need to be carried out to clarify the pathogenic mechanism in red cedar asthma, as this may help us to understand the pathogenic mechanism of nonatopic or intrinsic asthma in general.

\section{Amines}

Various secondary, tertiary and quarternary amines, either aliphatic, heterocyclic or aromatic, have been reported to cause occupational asthma [114]. These chemicals are found in primary manufacturing and in secondary industries, such as the rubber, cosmetics, shellac, fur and hair dye industries, aluminium soldering, acrylate paint, and photography development [115].

Amines have been shown to cause occupational asthma in workers exposed to epoxy resins, which were produced by amines acting as cross-linking agents binding the resin molecules together [114]. Ethylenediamine caused occupational asthma in the beauty culture industry and among radiographers and photographers who develop films [115]. Another amine, piperazine, is used as an anthelminthic drug [116]. A survey of 131 workers exposed to piperazine and ethylenediamine revealed that $8 \%$ were asthmatic [117]. Specific IgE antibodies to piperazine-HSA conjugate were detected in five out of 72 exposed workers [117]. The mechanism by which amines cause asthma remains unclear.

\section{Colophony and fluxes}

Colophony is widely-used as a flux in electronic industries to prevent corrosion. It is obtained from pine trees containing abietic acid. The mechanism of occupational asthma due to colophony is not known at present. A specific challenge test induced isolated immediate, isolated late, or dual asthmatic reaction in sensitized subjects. In a survey of 446 electronic workers, a prevalence of work-related symptoms was found in 22\% [118]. Atopy was a weak predisposing factor and smoking was not a determinant of work-related symptoms. There was a relationship between the degree of exposure and the prevalence of work-related symptoms. A follow-up study of 39 workers with asthma due to colophony exposure showed that symptoms persisted in half of them up to 4 yrs after exposure ceased [119].

Other soldering fluxes that can cause occupational asthma include zinc chloride and ammonium chloride [120], as well as one containing polyether alcohol-polypropylene glycol [121].

\section{Pharmaceutical products}

Whilst a number of pharmaceutical products have been shown to cause occupational asthma via an IgE-dependent mechanism, such as psyllium, ipecacuanha, pancreatic and glandular extracts, there are others that can cause occupational asthma via as yet unidentified mechanisms. These include several antibiotics, such as penicillins, amoxycillin, ampicillin, penicillamine, cephalosporins, phenyglycine acid chloride, and spiramycin [122]. Many of the cases were proven by specific challenge tests. Several nonantibiotic drugs can also cause occupational asthma, such as tylosin tartrate [123], alpha-methyldopa [124], amprolium hydrochloride [125], and morphine [126].

\section{Miscellaneous}

Exposure to many other chemical compounds in industries, such as chloramine $\mathrm{T}$, a sterilizing agent used in the food and beverage industry [127], persulphate salts used among hairdressers [128], diazonium salts in photo-copying process [129], reactive dyes in textile industry [130] and azobisformamide in plastics industry can give rise to occupational asthma [131]. It will not be possible to discuss each one of them in detail. Readers should refer 
to table 1 in the Appendix and the text book "Asthma in the Workplace" [3, 4].

\section{Agents causing occupational asthma through nonimmunological mechanisms}

Nonimmunological occupational asthma may or may not occur after a latency period of exposure to an agent(s) which does not induce immune sensitization as determined by currently available technology. The main distinction between this type of occupational asthma and immunologically-dependent ones is that in the majority of cases re-exposure of the affected subjects to small amounts of the offending agent does not reproduce the symptoms. Several types of occupational asthma belong to this category, and are described briefly below.

\section{Reactive Airways Dysfunction Syndrome (RADS)}

This syndrome was originally coined by BROOKS and co-workers [132] in 1985 , to describe 10 subjects who developed symptoms of asthma and NSBH after one single exposure to high levels of an irritant vapour, fume or smoke. None of the subjects had a previous history of respiratory symptoms. Respiratory symptoms and NSBH persisted for about 3 yrs after the initial event. The incriminated exposure was either short-lived, often lasting just a few minutes or, on occasions, was as long as $12 \mathrm{~h}$. There was a time interval between exposure and development of symptoms, varying from several minutes to several hours. The exposure was usually due to an accident or a situation where there was very poor ventilation and high exposure. Bronchial biopsies were performed on two cases. Whilst there was evidence of epithelial injury, with bronchial wall inflammation, the cells were lymphocytes and plasma cells; eosinophils were not found. In addition, there was no evidence of mucous gland hyperplasia, basement membrane thickening or smooth muscle hyperplasia. However, more recent biopsy data on subjects with this syndrome revealed typical histopathological features of asthma [133].

The incriminating agents were all irritants, including floor sealant, heated acid, fumigating fog, metal coating remover, acetic acid [134], smoke inhalation, TDI, and ammonia fumes [133].

Since re-exposure of these subjects to low levels of the incriminating agent did not reproduce symptoms, the diagnosis is a clinical one based on the history. The number of case reports is limited. The outcome of these subjects has not been as well documented as other types of occupational asthma. The syndrome needs to be studied in more detail to define it better.

Although BROOKS and co-workers [132] first coined this syndrome as RADS, there have been reports of persistent symptoms and a single, high concentration environmental or occupational irritant exposure. Five cases of accidental exposure to high levels of sulphur dioxide have been reported, with three survivors developing severe and another showing a mild degree of airflow obstruction [135]. A man aged 50 yrs developed obstructive airways disease after exposure to high concentration of ammonia vapours [136]. Several other studies of the sequelae of chlorine gas exposure showed similar findings $[137,138]$.

There are no data on the prevalence of this syndrome. The host risk factors are not known. A recent review of 59 consecutive cases of occupational asthma in the Toronto area in Canada showed that $17 \%$ were caused by exposure to irritants, suggesting that this syndrome is not that uncommon [139]. Longitudinal data are not available to indicate clearly that these subjects had no evidence of NSBH before the incident.

The pathogenesis of RADS is not clear. It has been postulated that the high level of exposure induces massive airway injury, followed by activation of nonadrenergic, noncholinergic (NANC) pathways via axon reflexes and the onset of neurogenic inflammation [133]. Nonspecific macrophage activation and mast cell degranulation may also occur, releasing proinflammatory mediators, with recruitment of inflammatory cells to the site of injury [133]. Epithelial injury has been shown to reduce the availability of an epithelial-derived relaxing factor and decrease neutral endopeptidase, leading to activation of the NANC nerves. As with other aspects of this syndrome, more research is necessary.

\section{Potroom asthma}

Potroom asthma has been reported among workers on potlines in aluminum smelting plants for many years [140]. Potroom workers are exposed to a number of contaminants, including particulate and gaseous fluoride, hydrofluoric acid, sulphur dioxide and hydrocarbons. The agent responsible for potroom asthma has not yet been identified. It has been postulated that the air contaminants in the potroom, if present in high concentrations, may induce asthma, as in RADS. The latent period between onset of exposure and the onset of symptoms varied from one week to 10 yrs [140]. Potroom asthma has been reported more frequently in smelters in Australia and Norway than in North America.

\section{Machining fluid}

Workers exposed to machining fluid can develop workrelated asthma [141]. Machining fluids are contaminated with trace metals, additives such as antioxidants, detergents, anti-foam agents, and bactericidal agents. The latter are necessary to prevent the growth of bacteria and fungi. In addition to well-defined cases of asthma, crossshift change in forced expiratory volume in one second $\left(\mathrm{FEV}_{1}\right)$ of less than $10 \%$ was reported in $24 \%$ of the heavily exposed and in $10 \%$ of the least exposed machinists [141]. The pathogenesis is not known, although the machining fluid is likely to act as an irritant.

\section{Formaldehyde}

Formaldehyde is an irritant at high concentrations, but a sensitizer in lower concentrations. Formaldehyde is 
widely used in hospital environments, furniture manufacture and as insulation in buildings in the 1980s. In a prevalence study of 230 workers exposed to formaldehyde at work, 12 had significant bronchoconstriction at levels of 1-2 ppm during specific challenge tests [142]. Attempts to detect specific antibodies in the sera of workers exposed to formaldehyde have so far been unsuccessful [143].

\section{Summary}

This review gives a brief summary of the more commonly encountered aetiological causes of occupational asthma. Interested readers should refer to the textbook "Asthma in the Workplace" edited by BERNSTEIN et al. [4]. With the introduction of more chemicals into the workplace, the list is likely to increase. It should be emphasized that the absence of the suspected agent in any listing of aetiological causes of occupational asthma should not exclude the diagnosis. An international effort to prepare a data base similar to the Minitel System in France would be most helpful to clinicians and investigators in this field [144].

\section{References}

1. Meredith SK, Taylor VM, McDonald JC. Occupational respiratory disease in the United Kingdom, 1989: a report to the British Thoracic Society and the Society of Occupational Medicine by the SWORD project group. Br J Ind Med 1991; 48: 292-298.

2. Lagier F, Cartier A, Malo JL. Medico-legal statistics on occupational asthma in Quebec between 1986 and 1988. Rev Mal Respir 1990; 7: 337-341.

3. Chan-Yeung M, Malo JL. Compendium I. Table of the major inducers of occupational asthma. In: Bernstein IL, Chan-Yeung M, Malo JL, Bernstein DI, eds. Asthma in the Workplace. New York, Marcel Dekker Inc., 1993; pp. 595-623.

4. Bernstein IL, Chan-Yeung M, Malo JL, Bernstein DI. Asthma in the Workplace. New York, Marcel Dekker Inc., 1993.

5. Agius RM, Nee J, McGovern B, Robertson A. Structure activity hypothesis in occupational asthma caused by low molecular weight substances. Ann Occup Hyg 1991; 35: $129-137$.

6. Venables KM, Dally MB, Nunn AJ, et al. Smoking and occupational allergy in workers in a platinum refinery. Br Med J 1989; 299: 939-942.

7. Newman-Taylor AJ, Gordon S. Laboratory animal and insect allergy. In: Bernstein IL, Chan-Yeung M, Malo JL, Bernstein DI., eds. Asthma in the Workplace. New York, Marcel Dekker Inc., 1993; pp. 399-414.

8. Botham PA, Davies GE, Teasdale EL. Allergy to laboratory animals: a prospective study of its incidence and of the influence of atopy on its development. $\mathrm{Br} J$ Ind Med 1987; 44: 627-632.

9. Chan-Yeung M, Malo JL. Natural history of occupational asthma. In: Bernstein IL, Chan-Yeung M, Malo JL, Bernstein DI, eds. Asthma in the Workplace. New York, Marcel Dekker Inc., 1993; pp. 299-322.

10. Slovak AJM, Hill RN. Does atopy have any predictive value for laboratory animal allergy? A comparison of different concepts of atopy. $B r J$ Ind Med 1987; 44: $129-132$.

11. Reed CE, Swanson MC, Li JTC. Environmental monitoring of protein aeroallergens. In: Bernstein IL, ChanYeung M, Malo JL, Bernstein DI, eds. Asthma in the Workplace. New York, Marcel Dekker Inc., 1993; pp. 249-275.

12. Edwards RG, Beeson MF, Dewdney JM. Laboratory animal allergy: the measurement of airborne urinary allergens and the effects of different environmental conditions. Lab Animal 1983; 17: 235-239.

13. Gordon S, Tee RD, Lawson D, Wallace J, NewmanTaylor AJ. Reduction of airborne allergenic urine proteins from laboratory rats. Br J Ind Med 1992; 49: 416422.

14. Sakaguchi M, Inouye $S$, Kamimura H, Kimura M, Yamazaki S. Evaluation of countermeasures for reduction of mouse airborne allergens. Lab Animal Sci 1990; 40: 613-615.

15. Brennan NJ. Pig Butcher's asthma: case report and review of the literature. Ir Med J 1985; 78: 321-322.

16. Joliat TL, Weber RW. Occupational asthma and rhinoconjunctivitis from inhalation of crystalline bovine serum albumin powder. Ann Allergy 1991; 66: 301-304.

17. Bernstein DI, Smith AB, Moller DR, et al. Clinical and immunologic studies among egg-processing workers with occupational asthma. J Allergy Clin Immunol 1987; 80: 791-797.

18. Smith AB, Bernstein DI, London MA, et al. Evaluation of occupational asthma from airborne egg protein exposure in multiple settings. Chest 1990; 98: 398-404.

19. Warren CPW, Holford-Strevens V, Sinha RN. Sensitization in a grain handler to the storage mite Lepidoglyphus destructor (Schrank) Ann Allergy 1983; 50: 30-33.

20. Cuthbert OD, Brostoff J, Wraith DG, Brighton WD. "Barn allergy": asthma and rhinitis due to storage mites. Clin Allergy 1979; 9: 229-236.

21. Reunala T, Bjorksten F, Forstrom L, Kanerva L. IgEmediated occupational allergy to a spider mite. Clin Allergy 1983; 13: 383-388.

22. Lutsky I, Teichtahl H, Bar-Sela S. Occupational asthma due to poultry mites. J Allergy Clin Immunol 1984; 73: 56-60.

23. Frankland AW, Lunn JA. Asthma caused by the grain weevil. Br J Ind Med 1965; 22: 157-159.

24. Frankland AW. Locust sensitivity. Ann Allergy 1953; 11: 445-453.

25. Burge PS, Edge G, O'Brien IM, Harries MG, Hawkins R, Pepys J. Occupational asthma in a research centre breeding locusts. Clin Allergy 1980; 10: 355-363.

26. Spieksma FTM, Vooren PH, Kramps JA, Dijkman JH. Respiratory allergy to laboratory fruit flies (Drosophila melanogaster). J Allergy Clin Immunol 1986; 77: 108113.

27. Thiel H. Baker's asthma. Epidemiological and clinical findings: needs for prospective studies. In: JW Kerr, MA Ganderton, eds. Proceedings of invited symposia. Eleventh International Congress of Allergology and Clinical Immunology. 1983; London: pp. 429-433.

28. Block G, Tse KS, Kijek K, Chan H, Chan-Yeung M. Baker's asthma. Studies of the cross-antigenicity between different cereal grains. Clin Allergy 1984; 14: 177-185.

29. Blands J, Diamant B, Kallos P, Kallos-Deffner L, Lowenstein H. Flour allergy in bakers. I. Identification of allergenic fractions in flour and comparison of diagnostic methods. Int Arch Allergy Appl Immunol 1976; 52: 392-402.

30. Walsh BJ, Wrigley CW, Musk AW, Baldo BA. A comparison of the binding of $\operatorname{IgE}$ in the sera of patients 
with baker's asthma to soluble and insoluble wheat-grain proteins. J Allergy Clin Immunol 1985; 76: 23-28.

31. Klaustermeyer WB, Bardana EJ, Hale FC. Pulmonary hypersensitivity to Alternaria and Aspergillus in baker's asthma. Clin Allergy 1977; 7: 227-233.

32. Baur X, Fruhmann G, Haug B, Rasche B, Reiher W, Weiss W. Role of Aspergillus amylase in baker's asthma. Lancet 1986; i: 43.

33. Baur X, Sauer W, Weiss W. Baking additives as new allergens in baker's asthma. Respiration 1988; 54: 70-72.

34. Musk AW, Venables KM, Crook B, et al. Respiratory symptoms, lung function, and sensitisation to flour in a British bakery. Br J Ind Med 1989; 46: 636-642.

35. Malo JL, Ghezzo H, D'Aquino C, L'Archevêque J, Cartier A, Chan-Yeung M. Natural history of occupational asthma: relevance of type of agent and other factors in the rate of development of symptoms in affected subjects. J Allergy Clin Immunol 1992; 90: 937-944.

36. Block G, Tse KS, Kijek K, Chan H, Chan-Yeung M. Baker's asthma. Clin Allergy 1983; 13: 359-370.

37. Davies RJ, Green M, Schoefield NM. Recurrent nocturnal asthma after exposure to grain dust. Am Rev Respir Dis 1976; 114: 1011-1019.

38. Malo JL, Cartier A, L'Archevêque J, et al. Prevalence of occupational asthma and immunologic sensitization to psyllium among health personnel in chronic care hospitals. Am Rev Respir Dis 1990; 142: 1359-1366.

39. Busse WW, Schoenwetter WF. Asthma from psyllium in laxative manufacture. Ann Intern Med 1975; 83: 361-362.

40. Cartier A, Malo JL, Dolovich J. Occupational asthma in nurses handling psyllium. Clin Allergy 1987; 17: $1-6$.

41. Gauss WF, Alarie JP, Karol MH. Workplace allergenicity of a psyllium-containing bulk laxative. Allergy 1985; 40: 73-76.

42. Scott D. Psyllium-induced asthma. Postgrad Med 1987; 82: $160-167$.

43. Terho EO, Torkko M. Occupational asthma from psyllium laxatives. Duodecim 1980; 96: 1213-1216.

44. Bernton HS. The allergenicity of psyllium seed. Med Ann DC 1970; 39: 313-317.

45. Schwartz HJ, Arnold JL, Strohl KP. Occupational allergic rhinitis reaction to psyllium. J Occup Med 1989; 31 : 624-626.

46. Bardy JD, Malo JL, Séguin P, et al. Occupational asthma and IgE sensitization in a pharmaceutical company processing psyllium. Am Rev Respir Dis 1987; 135: $1033-1038$

47. Goransson K, Michaelson NG. Ispagula powder. An allergen in the work environment. Scand J Work Environ Health 1979; 5: 257-261.

48. Malo JL, Cartier A, L'Archevêque J, et al. Prevalence of occupational asthma and immunological sensitization to guar gum among employees at a carpet-manufacturing plant. J Allergy Clin Immunol 1990; 86: 562-569.

49. Spielman AD, Baldwin HS. Atopy to acacia (gum arabic). J Am Med Assoc 1933; 101: 444-445.

50. Bohner CB, Sheldon JM, Trenis JW. Sensitivity to gum acacia, with a report of ten cases of asthma in printers. J Allergy 1941; 12: 290-294.

51. Flindt MLH. Pulmonary disease due to inhalation of derivatives of Bacillus subtilis containing protelolytic enzyme. Lancet 1969; i: 1177-1181.

52. Pepys J, Longbottom JL, Hargreave FE, Faux J. Allergic reactions of the lungs to enzymes of Bacillus subtilis. Lancet 1969; 1: 1811-1814.
53. Newhouse ML, Tagg B, Pocock SJ, McEwan AC. An epidemiological study of workers producing enzyme washing powders. Lancet 1970; i: 689-693.

54. Bernstein IL. Enzyme allergy in populations exposed to long-term, low-level concentrations of household laundry products. J Allergy Clin Immunol 1972; 49: 219-237.

55. Perdu D, Lavaud F, Cossart C, et al. Enzymes des lessives: le risque de sensibilisation professionelle a-t-il disparu? Rev Mal Respir 1992; 9: 443-448.

56. Pepys J, Mitchell J, Hawkins R, Malo JL, Ashforth GK, Wilson ER. A longitudinal study of possible allergy to enzyme detergents. Clin Allergy 1985; 15: 101-116.

57. Bernstein DI, Malo JL. High molecular weight agents. In: Bernstein IL, Chan-Yeung M, Malo JL, Bernstein DI, eds. Asthma in the Workplace. New York, Marcel Dekker Inc., 1993; pp. 373-398.

58. Jyo T, Kohmoto K, Katsutani T, Otsuka T, Oka SD, Mitsui S. Hoya (sea-squirt) asthma. In: Occupational Asthma. London, Von Nostrand Reinhold, 1980; pp. 209-228.

59. Gaddie J, Legge JS, Friend JAR, Reid TMS. Pulmonary hypersensitivity in prawn workers. Lancet 1980; ii: $1350-1353$.

60. Cartier A, Malo J-L, Forest F, et al. Occupational asthma in snow crab-processing workers. J Allergy Clin Immunol 1984; 74: 261-269.

61. Zeiss CR, Patterson R. Acid anhydrides. In: Bernstein IL, Chan-Yeung M, Malo JL, Bernstein DI, eds. Asthma in the Workplace. New York, Marcel Dekker Inc., 1993; pp. 439-457.

62. Kern RA. Asthma and allergic rhinitis due to sensitisation tophthalic anhydride. Report of a case. J Allergy 1939; 10: 164-165.

63. Maccia CA, Bernstein IL, Emmett EA, Brooks SM. In vitro demonstration of specific $\operatorname{IgE}$ in phthalic anhydride hypersensitivity. Am Rev Respir Dis 1976; 113: 701704.

64. Zeiss CR, Wolkonsky P, Chacon R, et al. Syndromes in workers exposed to trimellitic anhydride. Ann Intern Med 1983; 98: 8-12.

65. Zeiss CR, Patterson R, Pruzansky JJ, Miller MM, Rosenberg M, Levitz D. Trimellitic anhydride-induced airway syndromes: clinical and immunologic studies. J Allergy Clin Immunol 1977; 60: 96-103.

66. Zeiss CR, Mitchell J, Van Peenen PFD, et al. Evaluation of an entire chemical plant related to trimellitic anhydride (TMA) exposure. J Allergy Clin Immunol 1990; 85: 190.

67. Venables KM, Topping MD, Howe W, Luczynska CM, Hawkins R, Newman Taylor AJ. Interaction of smoking and atopy in producing specific IgE antibody against a hapten protein conjugate. Br Med J 1985; 290: 201-204.

68. Venables KM, Topping MD, Nunn AJ, Howe W, NewmanTaylor AJ. Immunologic and functional consequences of chemical (tetrachlorophthalic anhydride)-induced asthma after four years of avoidance of exposure. J Allergy Clin Immunol 1987; 80: 212-218.

69. Bernstein IL, Brooks SM. Metals. In: Bernstein IL, Chan-Yeung M, Malo JL, Bernstein DI, eds. Asthma in the Workplace. New York, Marcel Dekker Inc., 1993; pp. 459-479.

70. Malo JL, Cartier A, Doepner M, Nieboer E, Evans S, Dolovich J. Occupational asthma caused by nickel sulfate. J Allergy Clin Immunol 1982; 69: 55-59.

71. Block GT, Yeung M. Asthma induced by nickel. $J$ Am Med Assoc 1982; 247: 1600-1602.

72. Kusaka Y, Nakano Y, Shirakawa T, Fujimura N, Kato 
M, Heki S. Lymphocyte transformation test with nickel in hard metal asthma: another sensitizing component of hard metal. Ind Health 1991; 29: 153-160.

73. Karasek ST, Karasek M. The use of platinum paper. Report of Illinois State Commission of Occupational Disease, Springfield, Illinois. 1911; 97.

74. Hunter D, Milton R, Perry KMA. Asthma caused by the complex salts of platinum. $\mathrm{Br} J$ Ind Med 1945; 2: 92-98.

75. Pepys J, Pickering CAC, Hughes EG. Asthma due to inhaled chemical agents: complex salts of platinum. Clin Allergy 1972; 2: 391-396.

76. Biagini RE, Bernstein IL, Gallagher JS, Moorman WJ, Brooks S, Gann PH. The diversity of reaginic immune responses to platinum and palladium metallic salts. $J$ Allergy Clin Immunol 1985; 76: 794-802.

77. Hughes EG. Medical surveillance of platinum refinery workers. J Soc Occup Med 1980; 30: 27-30.

78. Malo JL, Cartier A. Occupational asthma due to fumes of galvanized metal. Chest 1987; 92: 375-377.

79. Kawane H, Soejima R, Umeki S, Niki Y. Metal fume and asthma. Chest 1988; 93: 1116-1117.

80. Perrin B, Cartier A, Ghezzo H, et al. Reassessment of the temporal patterns of bronchial obstruction after exposure to occupational sensitizing agents. J Allergy Clin Immunol 1991; 87: 630-639.

81. Chan-Yeung M. Occupational asthma. Chest 1990; 98: 148S-161S.

82. Vandenplas O, Malo JL, Saetta M, Mapp CE, Fabbri L. Occupational asthma and extrinsic alveolitis due to isocyanates: current status and perspectives. $\mathrm{Br} J$ Ind Med 1993; 50: 213-228.

83. Butcher BT, Jones RN, O'Neil CE, et al. Longitudinal study of workers employed in the manufacture of toluene diisocyanate. Am Rev Respir Dis 1977; 116: 411-421.

84. Bignon J, Aron A, Li YJ, et al. HLA DQB1 and DPB1 alleles are associated with isocyanate-sensitive occupational asthma. Am Rev Respir Dis 1992: A321.

85. NIOSH recommended standard for occupational exposure to diisocyanates. US Department of Health, Education and Welfare, Public Health Service, Center for Disease Control, National Institute for Occupational Safety and Health. No. 78-125, 1979.

86. Karol MH. Concentration-dependent immunologic response to toluene diisocyanate (TDI) following inhalation exposure. Toxicol Appl Pharmacol 1983; 68: 229-241.

87. Cibulas W Jr, Murlas CG, Miller ML, et al. Toluene diisocyanate-induced airway hyperreactivity and pathology in the guinea-pig. J Allergy Clin Immunol 1986; 77: 828-834.

88. Kennedy AL, Stock MF, Alarie Y, Brown WE. Uptake and distribution of $14 \mathrm{C}$ during and following inhalation exposure to radioactive toluene diisocyanate. Toxicol Appl Pharmacol 1989; 100: 280-292.

89. Kennedy AL, Brown WE. Modification of airway proteins and induction of secondary responses by inhalation exposure to isocyanates. Am Rev Respir Dis 1989; 139: $387 \mathrm{~A}$

90. Banks DE, Rando RJ. Recurrent asthma induced by toluene diisocyanate. Thorax 1988; 43: 660-662.

91. Mapp CE, Corona PC, de Marzo N, Fabbri L. Persistent asthma due to isocyanates. A follow-up study of subjects with occupational asthma due to toluene diisocyanate. Am Rev Respir Dis 1988; 137: 1326-1329.

92. Paggiaro PL, Loi AM, Rossi O, et al. Follow-up study of patients with respiratory disease due to toluene diisocyanate (TDI). Clin Allergy 1984; 14: 463-469.
93. Allard C, Cartier A, Ghezzo H, Malo J-L. Occupational asthma due to various agents. Absence of clinical and functional improvement at an interval of four or more years after cessation of exposure. Chest 1989; 96: 10461049.

94. Lozewicz S, Assoufi BK, Hawkins R, Newman-Taylor AJ. Outcome of asthma induced by isocyanates. $\mathrm{Br} J$ Dis Chest 1987; 81: 14-27.

95. Patterson R, Hargreave FE, Grammer LC, Harris KE, Dolovich J. Toluene diisocyanate respiratory reactions I. Reassessment of the problem. Int Arch Allergy Appl Immunol 1987; 84: 93-100.

96. Bernstein IL. Isocyanate-induced pulmonary diseases: a current perspective. J Allergy Clin Immunol 1982; 70: 24-31.

97. Patterson R, Zeiss CR, Pruzansky JJ. Immunology and immunopathology of trimellitic anhydride pulmonary reactions. J Allergy Clin Immunol 1982; 70: 19-23.

98. Davies RJ, Butcher BT, O'Neil CE, Salvaggio JE. The in vitro effect of toluene diisocyanate on lymphocyte cyclic adenosine monophosphate production by isoproterenol, prostaglandin, and histamine. A possible mode of action. J Allergy Clin Immunol 1977; 60: 223-229.

99. Fabbri LM, Ciaccia A, Maestrelli P, Saetta M, Mapp CE. Pathophysiology of occupational asthma. In: Bernstein IL, Chan-Yeung M, Malo JL, Bernstein DI, eds. Asthma in the Workplace. New York, Marcel Dekker Inc., 1993; pp. 61-92.

100. Fabbri LM, Danieli D, Crescioli S, et al. Fatal asthma in a subject sensitized to toluene diisocyanate. Am Rev Respir Dis 1988; 137: 1494-1498.

101. Zammit-Tabona M, Sherkin M, Kijek K, Chan H, ChanYeung M. Asthma caused by diphenylmethane diisocyanate in foundry workers. Clinical, bronchial provocation, and immunologic studies. Am Rev Respir Dis 1983; 128: 226-230.

102. Vandenplas O, Malo JL, Dugas M, et al. Hypersensitivity pneumonitis-like reaction among workers exposed to diphenylmethane diisocyanate (MDI). Am Rev Respir Dis 1993; 147: 338-346.

103. Grammer LC, Eggum P, Silverstein M, Shaughnessy MA, Liotta JL, Patterson R. Prospective immunologic and clinical study of a population exposed to hexamethylene diisocyanate. J Allergy Clin Immunol 1988; 82: 627633.

104. Chan-Yeung M, Barton GM, MacLean L, Grzybowski S. Occupational asthma and rhinitis due to western red cedar (Thuja plicata). Am Rev Respir Dis 1973; 108: 1094-1102.

105. Chan-Yeung M. Western red cedar and other wood dusts. In: Bernstein IL, Chan-Yeung M, Malo JL, Bernstein DI, eds. New York, Marcel Dekker Inc., 1993; pp. 503-531.

106. Vedal S, Chan-Yeung M, Enarson D, et al. Symptoms and pulmonary function in western red cedar workers related to duration of employment and dust exposure. Arch Environ Health 1986; 41: 179-183.

107. Brooks SM, Edwards JJ, Apol A, Edwards FH. An epidemiologic study of workers exposed to western red cedar and other wood dust. Chest 1981; 80: 30-32.

108. Chan-Yeung M, Desjardins A. Nonspecific bronchial hyperresponsiveness and dust exposure in patients with asthma due to western red cedar. Serial observations before and after the development of symptoms. Am Rev Respir Dis 1992; 146: 1606-1609.

109. Côté J, Kennedy S, Chan-Yeung M. Outcome of patients with cedar asthma with continuous exposure. Am Rev Respir Dis 1990; 141: 373-376. 
110. Tse KS, Chan H, Chan-Yeung M. Specific IgE antibodies in workers with occupational asthma due to western red cedar. Clin Allergy 1982; 12: 249-258.

111. Chan-Yeung M, Chan H, Salari H, Lam S. Histamine, leukotrienes and prostaglandins release in bronchial fluid during plicatic acid-induced bronchoconstriction. J Allergy Clin Immunol 1989; 84: 762-768.

112. Lam S, LeRiche J, Phillips D, Chan-Yeung M. Cellular and protein changes in bronchial lavage fluid after late asthmatic reaction in patients with red cedar asthma. $J$ Allergy Clin Immunol 1987; 80: 44-50.

113. Frew AJ, Chan H, Dryden P, Salari H, Lam S, ChanYeung M. Immunological studies of the mechanisms of occupational asthma due to western red cedar. J Allergy Clin Immunol 1993; 92 (3): 466-478.

114. Hagmar L, Nielsen J, Skerfving S. Clinical features and epidemiology of occupational obstructive respiratory disease caused by small molecular weight organic chemicals. Epidemiology of allergic diseases. Monogr Allergy 1987; 21: 42-58.

115. Gelfand HH. Respiratory allergy due to chemical compounds encountered in the rubber, lacquer, shellac, and beauty culture industries. J Allergy 1963; 34: 374-381.

116. McCullagh SF. Allergenicity of piperazine: a study in environmental aetiology. $\mathrm{Br}$ J Ind Med 1968; 25: 319325 .

117. Hagmar L, Welinder H. Prevalence of specific IgE antibodies against piperazine in employees of a chemical plant. Int Arch Allergy Appl Immunol 1986; 81: 12-16.

118. Herks WH, Burge PS, Rehahn M, Green M. Workrelated respiratory disease in employees leaving an electronics factory. Thorax 1979; 34: 19-22.

119. Burge PS. Occupational asthma in electronics workers caused by colophony fumes: follow-up of affected workers. Thorax 1982; 37: 348-353.

120. Weir DC, Robertson AS, Jones S, Burge PS. Occupational asthma due to soft corrosive soldering fluxes containing zinc chloride and ammonium chloride. Thorax 1989; 44: 220-223.

121. Stevens JJ. Asthma due to soldering flux: a polyether alcohol-polypropylene glycol mixture. Ann Allergy 1976; 36: 419-422.

122. Lee HS, Wang YT, Yeo CT, Tan KT, Ratnam KV. Occupational asthma due to tylosin tartrate. Br J Ind Med 1989; 46: 498-499.

123. Harries MG, Newman Taylor A, Wooden J, MacAuslan A. Bronchial asthma due to alpha-methyldopa. $\mathrm{Br} \mathrm{Med}$ $J$ 1979; 1 (6176): 1461.

124. Greene SA, Freedman S. Asthma due to inhaled chemical agents: amprolium hydrochloride. Clin Allergy 1976; 6: 105-108.

125. Biagini RE, Klincewicz SL, Henningsen GM, et al. Antibodies to morphine in workers exposed to opiates at a narcotics manufacturing facility and evidence for similar antibodies in heroin abusers. Life Sci 1990; 47: 897-908.

126. Bourne MS, Flindt MLH, Walker JM. Asthma due to industrial use of chloramine. Br Med J 1979; 2: 10-12.

127. Blainey AD, Ollier S, Cundell D, Smith RE, Davies RJ. Occupational asthma in a hairdressing salon. Thorax 1986; 41: $42-50$.
128. Armeli G. Bronchial asthma from diazonium salts. Med Lav 1968; 59: 463-466.

129. Alanko K, Keskinen H, Byorksten F, Ojanen S. Immediate-type hypersensitivity to reactive dyes. Clin Allergy 1978; 8: 25-31.

130. Malo JL, Pineau L, Cartier A. Occupational asthma due to azobisformamide. Clin Allergy 1985; 15: 261264.

131. Malo JL, Bernstein IL. Other chemical substances causing occupational asthma. In: Bernstein IL, Chan-Yeung M, Malo JL, Bernstein DI, eds. Asthma in the Workplace. New York, Marcel Dekker Inc., 1993; pp. 481-502.

132. Brooks SM, Weiss MA, Bernstein IL. Reactive airways dysfunction syndrome (RADS). Persistent asthma syndrome after high level irritant exposures. Chest 1985; 88: 376-384.

133. Brooks SM, Bernstein IL. Reactive airways dysfunction syndrome or irritant-induced asthma. In: Bernstein IL, Chan-Yeung M, Malo JL, Bernstein DI, eds. Asthma in the Workplace. New York, Marcel Dekker Inc., 1993; pp. 533-549.

134. Kern DG. Outbreak of the reactive airways dysfunction syndrome after a spill of glacial acetic acid. Am Rev Respir Dis 1991; 144: 1058-1064.

135. Charan NB, Myers CG, Lakshminarayan S, Spencer TM. Pulmonary injuries associated with acute sulphur dioxide inhalation. Am Rev Respir Dis 1979; 119: 555560.

136. Flury KE, Ames DE, Rodarte JR, Rodgers R. Airway obstruction due to inhalation of ammonia. Mayo Clin Proc 1983; 58: 389-393.

137. Salisbury DA, Enarson DA, Chan-Yeung M, Kennedy SM. First-aid reports of acute chlorine gassing among pulpmill workers as predictors of lung health consequences. Am J Ind Med 1991; 20: 71-81

138. Kennedy SM, Enarson DA, Janssen RG, Chan-Yeung M. Lung health consequences of reported accidental chlorine gas exposures among pulpmill workers. Am Rev Respir Dis 1991; 143: 74-79.

139. Tarlo SM, Broder I. Irritant-induced occupational asthma. Chest 1989; 96: 297-300.

140. Abramson MJ, Wlodarczyk JH, Saunders NA, Hensley MJ. Does aluminium smelting cause lung disease. Am Rev Respir Dis 1989; 139: 1042-1057.

141. Kennedy SM, Greaves IA, Kriebel D, Eisen EA, Smith TJ, Woskie SR. Acute pulmonary responses among automobile workers exposed to aerosols of machining fluids. Am J Ind Med 1989; 15: 627-641.

142. Nordman H, Keskinen H, Tuppurainen M. Formaldehyde asthma: rare or overlooked? J Allergy Clin Immunol 1985; 75: 91-99.

143. Grammer LC, Harris KE, Shaughnessy MA, et al. Clinical and immunologic evaluation of 37 workers exposed to gaseous formaldehyde. J Allergy Clin Immunol 1990; 86: 177-181.

144. Perrin B, Dhivert H, Godard P, Bousquet J, Michel FB. The telematic information service (Minitel) on occupational asthma in France. In: Bernstein IL, Chan-Yeung M, Malo JL, Bernstein DI, eds. Asthma in the Workplace. New York, Marcel Dekker Inc., 1993; pp. 635-638. 


\section{Appendix}

Table 1. - Selection of key references in occupational asthma (Reference list at end of table)

\begin{tabular}{|c|c|c|c|c|c|c|c|c|c|}
\hline Agents & Occupation & {$[\operatorname{Ref}]$} & $\begin{array}{c}\text { Subjects } \\
\mathrm{n}\end{array}$ & $\begin{array}{c}\text { Prevalence } \\
\%\end{array}$ & $\begin{array}{l}\text { Skin } \\
\text { test }\end{array}$ & Specific IgE & $\begin{array}{c}\text { Other } \\
\text { immunologic }\end{array}$ & $\begin{array}{l}\text { Broncho- } \\
\text { provocation } \\
\text { test }\end{array}$ & $\begin{array}{l}\text { Other } \\
\text { evidence }\end{array}$ \\
\hline \multicolumn{10}{|c|}{ High molecular weight agents } \\
\hline Laboratory & Laboratory workers & [1] & 296 & 13 & $17 \%+$ & $34 \%$ of $255+$ & ND & $\mathrm{ND}$ & \\
\hline animal & & [2] & 5 & NA & $100 \%+$ & $100 \%+$ & Neg precipitin & $100 \%+$ & \\
\hline Cow dander & Agricultural workers & [3] & 49 & NA & $100 \%$ & ND & Immunoblotting & ND & \\
\hline Chicken & Poultry workers & {$[4,5]$} & 14 & NA & $79 \%+$ & $79 \%+$ & ND & $1 / 1+$ & \\
\hline Pig & Butcher & [6] & 1 & $\mathrm{NA}$ & ND & + & ND & ND & $\begin{array}{c}+ \text { PEFR } \\
\text { monitoring }\end{array}$ \\
\hline Frog & Frog catcher & [7] & 1 & NA & + & + & Neg precipitin & ND & \\
\hline Lactoserum & Dairy industry & [8] & 1 & NA & + & ND & + basophil & + & \\
\hline Casein (cow's milk) & Tanner & [9] & 1 & NA & ND & + & $\begin{array}{l}\text { Degranulation } \\
\text { ND }\end{array}$ & + & \\
\hline Bat guano & Various & {$[10]$} & 7 & NA & + & + & RAST inhibition & ND & \\
\hline \multicolumn{10}{|l|}{ Insects } \\
\hline \multirow[t]{2}{*}{ Grain mite } & Farmers & [11] & 290 & 12 & $21 \%+$ & $19 \%$ of $219+$ & ND & ND & \\
\hline & Grain-store workers & [12] & 133 & 33 & $25+$ & $23 \%$ of $128+$ & ND & $1 / 1+$ & $\begin{array}{l}21 \% \text { of } 116 \\
\text { with }+\mathrm{PC}_{20}\end{array}$ \\
\hline \multirow[t]{2}{*}{ Locust } & Laboratory workers & [13] & 118 & 26 & $32 \%$ of $113+$ & Done & Specific IgG & ND & Reduced $\mathrm{FEV}_{1}$ \\
\hline & & [14] & 15 & 60 & $77 \%+$ & $53 \%$ & RAST inhibition & ND & \\
\hline Screw worm fly & Flight crews & [15] & 182 & 25 & $91 \%$ of $11+$ & ND & ND & ND & \\
\hline Cricket & Laboratory workers & {$[16]$} & 2 & NA & + & + & Passive transfer & + & \\
\hline Bee moth & Fish bait breeder & [17] & 1 & NA & + & ND & $\begin{array}{l}\text { Passive transfer } \\
\text { Histamine release }\end{array}$ & $\begin{array}{c}\mathrm{ND} \\
+\end{array}$ & \\
\hline Moth, butterfly & Entomologists & {$[18]$} & 2 & NA & + & ND & ND & ND & \\
\hline $\begin{array}{l}\text { Mexican bean } \\
\text { weevil }\end{array}$ & Seed house & [19] & 2 & $\mathrm{NA}$ & + & ND & Passive transfer & ND & \\
\hline Fruit fly & Laboratory workers & [20] & 22 & 32 & $27 \%+$ & $27 \%+$ & RAST inhibition & $21 \%$ of $14+$ & \\
\hline Honeybee & Honey processors & [21] & 1 & NA & + & + & ND & + & \\
\hline L. caesar larvae & Anglers & [22] & 5 & NA & $75 \%$ of $4+$ & $80 \%$ of $5+$ & RAST inhibition & $1 / 1+$ & \\
\hline Lesser mealworm & $\begin{array}{l}\text { Grain and poultry } \\
\text { workers }\end{array}$ & [23] & 3 & NA & $\mathrm{Neg}$ & $100 \%$ of $3+$ & RAST inhibition & ND & \\
\hline Fowl mite & Poultry workers & [24] & 13 & NA & $77 \%+$ & $60 \%$ & ND & $1 / 1+$ & \\
\hline Barn mite & Farmers & [25] & 38 & NA & $100 \%+$ & $\sim 100 \%$ & ND & ND & \\
\hline Mites and parasites & Flour handlers & [26] & 12 & NA & ND & + & ND & ND & \\
\hline Acarian & Apple growers & [27] & 4 & NA & + & ND & Neg precipitins & ND & \\
\hline Daphnia & Fish food-store & [28] & 2 & NA & + & + & ND & $2 / 2+$ & \\
\hline Weeping fig & Plant keepers & [29] & 84 & 7 & $21 \%+$ & $21 \%$ & ND & $100 \%$ of $6+$ & $\mathrm{PC}_{20}$ \\
\hline Sheep blowfly & Technicians & [30] & 53 & 24 & ND & $67 \%$ of $15+$ & ND & ND & \\
\hline Silkworm & Silk workers & [31] & 53 & $34 \%$ & ND & ND & ND & ND & \\
\hline \multicolumn{10}{|l|}{ Plants } \\
\hline \multirow[t]{3}{*}{ Grain dust } & Grain elevators & [32] & 610 & $\sim 40$ & $9 \%+$ & ND & Neg precipitins & ND & $\begin{array}{l}\text { Spirometry } \\
\text { pre-post shift }\end{array}$ \\
\hline & & {$[33,34]$} & 502 & $47-$ & $\sim 50 \%$ of 51 exposed + & ND & ND & ND & $\mathrm{FEV}_{1}$, volumes \\
\hline & & [35] & 22 & NA & $0 \%+$ & ND & Neg precipitins & $27 \%+$ & $50 \% \mathrm{PC}_{20}+$ \\
\hline \multirow[t]{3}{*}{$\begin{array}{l}\text { Wheat, rye } \\
\text { and soya flour }\end{array}$} & Bakers, millers & [36] & 279 & 35 & $\begin{array}{c}9 \%+ \\
\text { (cereals) }\end{array}$ & ND & ND & ND & $\mathrm{FEV}_{1}, \mathrm{PC}_{20}$ \\
\hline & & [37] & 7 & 100 & $100 \%+$ & $100 \%+$ & $100 \%$ neg & $57 \%+$ & \\
\hline & & [38] & 9 & 100 & ND & $100 \%+$ & $\begin{array}{l}\text { Western blotting, } \\
\text { etc. }\end{array}$ & ND & \\
\hline Lathyrus sativus & Flour handler & [39] & 1 & NA & + & ND & + precipitins & + & \\
\hline Vicia sativa & Farmer & [40] & 1 & NA & + & + & $\begin{array}{l}\text { + precipitins, } \\
\text { passive transfer }\end{array}$ & + & \\
\hline Buckwheat & Bakers & [41] & 3 & NA & $100 \%+$ & ND & ND & ND & \\
\hline Gluten & Bakers & [42] & 1 & NA & + & + & RAST inhibition & + & \\
\hline \multirow[t]{3}{*}{ Coffee bean } & Food processor & [43] & 372 & 34 & $24 \%+$ & $12 \%+$ & ND & ND & Function tests \\
\hline & & [44] & 45 & 9 & $9-40 \%+$ & ND & ND & ND & Spirometry \\
\hline & & [45] & 22 & NA & $82 \%+$ & $50 \%+$ & ND & $67 \%$ of $12+$ & $\mathrm{PC}_{20}+$ in 14 \\
\hline Castor bean & Oil industry & [46] & 14 & NA & $100 \%+$ & $100 \%+$ & ND & ND & \\
\hline Tea & Tea processors & [47] & 3 & NA & $100 \%$ neg & ND & ND & $100 \%$ of $3+$ & \\
\hline Herbal tea & Herbal tea processors & [48] & 1 & NA & ND & Neg & ND & + & \\
\hline
\end{tabular}

The number of subjects tested is not specified if it included all subjects; otherwise it is mentioned. \$: Prevalence of symptoms compatible with work-related asthma unless otherwise stated. *: based on challenge data; **: presence of bronchial hyperresponsiveness; ${ }^{*}$ : subjects with symptoms. All proportions including 3 or more as the denom-

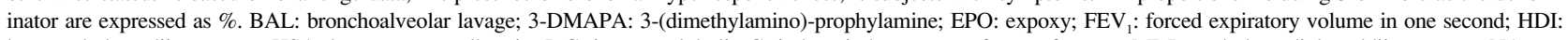
hexamethylene diisocyanate; HSA: human serum albumin; IgG: immunoglobulin G; indust: industry; manuf: manufacturer; MDI: methylene diphenyldiisocyanate; NA: not applicable; ND: not done; neg: negative. PCA: passive cutaneous analphylaxis; $\mathrm{PC}_{20}$ : provocative concentration producing a $20 \%$ fall in $\mathrm{FEV}{ }_{1}$; $\mathrm{PEFR}$ : peak expiratory flow rate: PPI: polymethylene polyphenylisocyanate; RAST: radioallergosorbent test; TDI: toluene diisocyanate; 
Table 1. continued

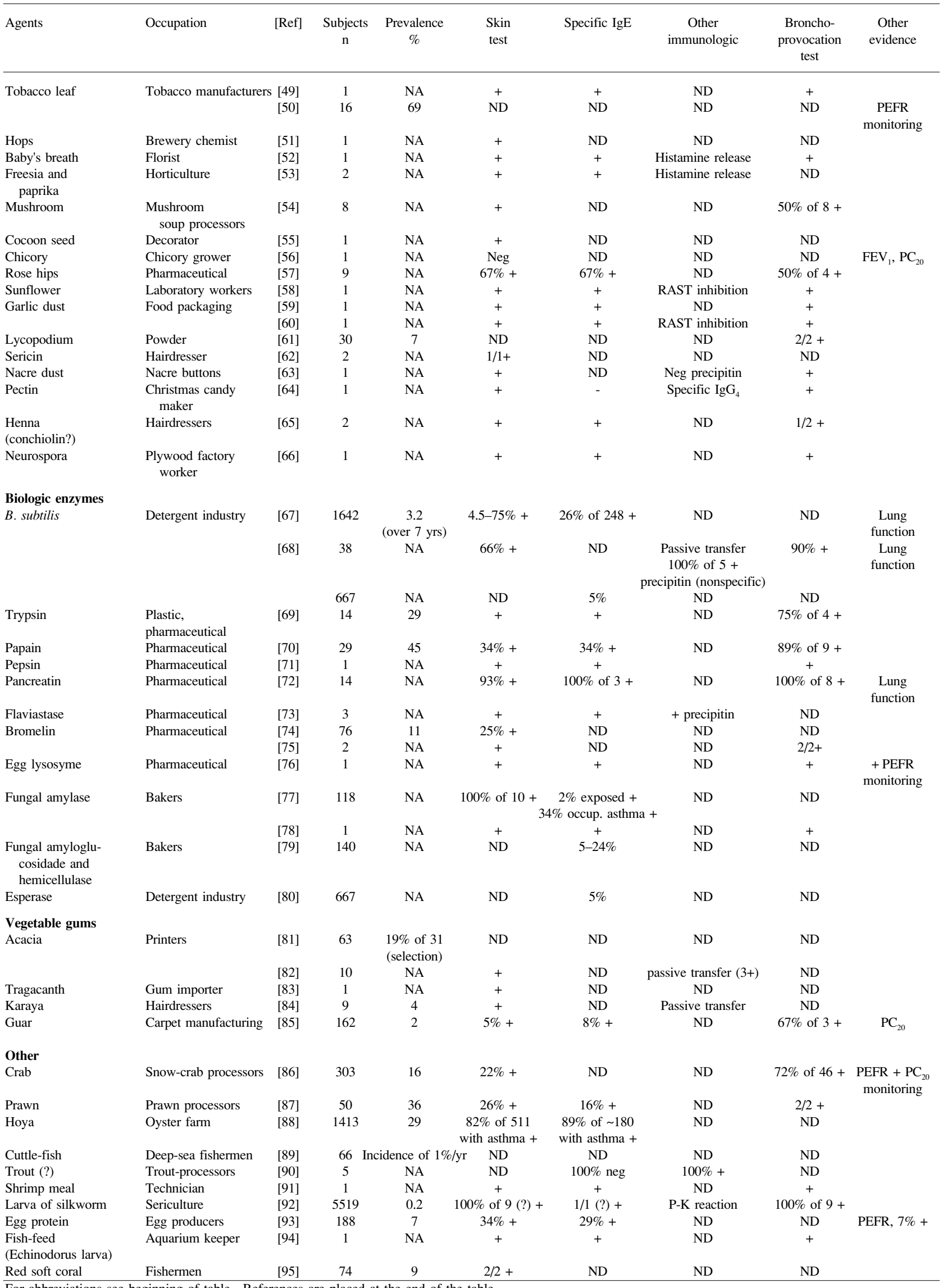

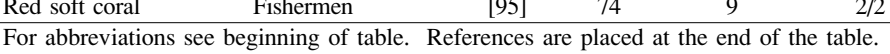


Table 1. continued

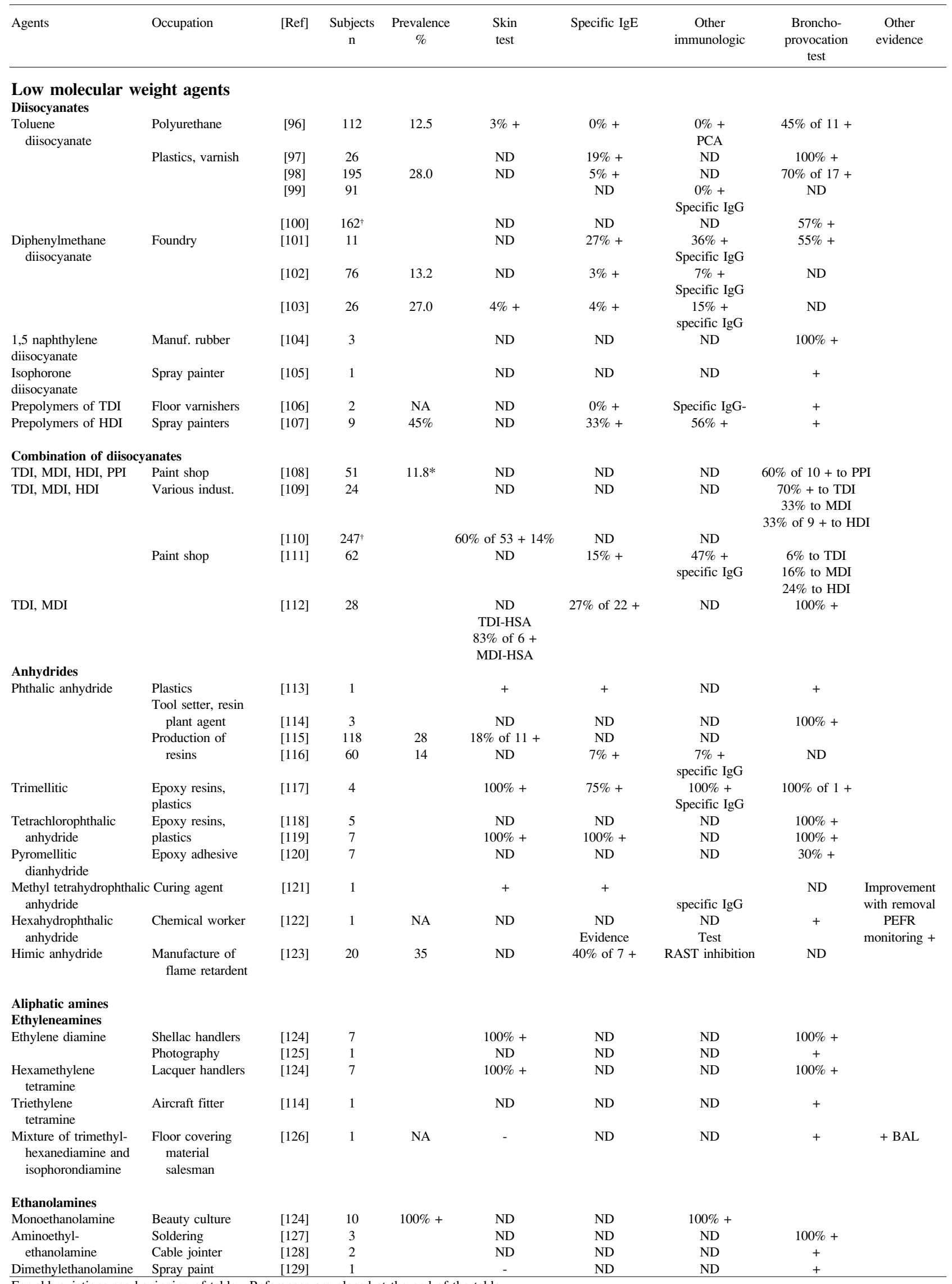

For abbreviations see beginning of table. References are placed at the end of the table. 


\begin{tabular}{|c|c|c|c|c|c|c|c|c|c|}
\hline Agents & Occupation & {$[\mathrm{Ref}]$} & $\begin{array}{c}\text { Subjects } \\
\mathrm{n}\end{array}$ & $\begin{array}{c}\text { Prevalence } \\
\%\end{array}$ & $\begin{array}{l}\text { Skin } \\
\text { test }\end{array}$ & Specific IgE & $\begin{array}{c}\text { Other } \\
\text { immunologic }\end{array}$ & $\begin{array}{l}\text { Broncho- } \\
\text { provocation } \\
\text { test }\end{array}$ & $\begin{array}{l}\text { Other } \\
\text { evidence }\end{array}$ \\
\hline \multicolumn{10}{|l|}{ Other } \\
\hline (3-DMAPA) & Ski manufacture & {$[130]$} & 34 & 11.7 & ND & ND & ND & ND & $\begin{array}{c}\text { Cross-shift } \\
\text { changes in FEV }\end{array}$ \\
\hline \multicolumn{10}{|l|}{ Heterocyclic amines } \\
\hline \multirow{3}{*}{$\begin{array}{l}\text { Piperazine } \\
\text { hydrochloride }\end{array}$} & Chemist & [131] & 2 & & $50 \%$ & ND & ND & $100 \%$ & \\
\hline & Pharmaceutical & [132] & 131 & 11.4 & ND & ND & ND & $100 \%$ of $1+$ & \\
\hline & Chemical plant & [133] & 2 & & $50 \%+$ & $100 \%+$ & $\mathrm{ND}$ & ND & \\
\hline N-methylmorpholine & & [134] & 48 & $16.6^{* *}$ & ND & ND & ND & ND & \\
\hline \multicolumn{10}{|l|}{ Aromatic amines } \\
\hline $\begin{array}{l}\text { Paraphenylene } \\
\text { diamine }\end{array}$ & Fur dyeing & [135] & 80 & 37.0 & $66 \%+$ & ND & ND & $74 \%+$ & \\
\hline \multicolumn{10}{|l|}{ Mixture of amines } \\
\hline EPO 60 & Mould maker & [136] & 1 & NA & ND & ND & ND & + & \\
\hline \multicolumn{10}{|l|}{ Fluxes } \\
\hline \multirow[t]{4}{*}{ Colophony } & $\begin{array}{l}\text { Electronic } \\
\text { workers }\end{array}$ & [137] & 34 & & ND & ND & ND & $100 \%+$ & \\
\hline & Manufacture & [138] & 68 low & 4 & $\mathrm{ND}$ & ND & $\mathrm{ND}$ & ND & \\
\hline & solder flux & & 14 med & 21 & ND & ND & $\mathrm{ND}$ & ND & \\
\hline & & & 6 high & 21 & ND & ND & $\mathrm{ND}$ & ND & \\
\hline $\begin{array}{l}\text { Zinc chloride and } \\
\text { ammonium chloride } \\
\text { flux }\end{array}$ & Metal jointing & [139] & 2 & & ND & ND & ND & + & Changes in $\mathrm{PC}_{20}$ \\
\hline $\begin{array}{l}95 \% \text { alkylarul polyether } \\
\text { alcohol }+5 \% \text { polypro- } \\
\text { pylene glycol }\end{array}$ & $\begin{array}{l}\text { Electronic } \\
\text { assembler }\end{array}$ & [140] & 1 & & ND & ND & ND & + & \\
\hline \multicolumn{10}{|l|}{ Wood dust or bark } \\
\hline \multirow{5}{*}{$\begin{array}{l}\text { Western red cedar } \\
\quad \text { (Thuja plicata) }\end{array}$} & Carpentry & [141] & 35 & & ND & ND & ND & ND & Improvement on \\
\hline & Furniture making & [142] & 1320 & 3.4 & $1.9 \%+$ & ND & ND & ND & removal \\
\hline & $\begin{array}{l}\text { Cabinet-making, } \\
\text { carpentry }\end{array}$ & [143] & 22 & & $100 \%-$ & $\begin{array}{l}\mathrm{ND} \\
\text { precipitin }\end{array}$ & $100 \%-$ & $82 \%+$ & \\
\hline & Sawmill & [144] & 185 & & $100 \%-$ & ND & ND & $100 \%+$ & \\
\hline & & [145] & 652 & 4.1 & $100 \%-$ & ND & ND & ND & Questionnaire \\
\hline \multirow{3}{*}{$\begin{array}{l}\text { California redwood } \\
\text { (Sequoia sempervirens) }\end{array}$} & Woodcarvers & [146] & 2 & & - & ND & - & + & \\
\hline & & & & & & & precipitin & & \\
\hline & Carpenter & [147] & 1 & & ND & ND & ND & + & \\
\hline $\begin{array}{l}\text { Cedar of Lebanon } \\
\quad(\text { Cedra libani })\end{array}$ & & [148] & 6 & & $17 \%+$ & ND & $\begin{array}{c}100 \%- \\
\text { precipitin }\end{array}$ & ND & \\
\hline $\begin{array}{l}\text { Cocabolla } \\
\text { (Dalbergia retusa) }\end{array}$ & & [149] & 3 & & $100 \%-$ & ND & $\mathrm{ND}$ & ND & $\begin{array}{l}\text { Improvement on } \\
\text { removal }\end{array}$ \\
\hline Iroko & & {$[150]$} & 1 & & + & ND & $\stackrel{+}{+}$ & + & \\
\hline (Chlorophora excelsa) & Carpenter & [151] & 1 & & ND & ND & $\mathrm{ND}$ & + & \\
\hline Oak (Quercus robur) & & [152] & 1 & & - & ND & $\stackrel{+}{+}$ & + & \\
\hline Mahogany (Shoreal Sp.) & & [152] & 1 & & - & ND & $\stackrel{+}{+}$ & + & \\
\hline Abiruana (Pouteria) & & [153] & 2 & & + & ND & $\begin{array}{c}- \\
\text { precipitin }\end{array}$ & + & \\
\hline $\begin{array}{l}\text { African maple } \\
\quad \text { (Triplochiton scleroxylo }\end{array}$ & & [154] & 2 & & + & + & $\begin{array}{l}\text { Passive } \\
\text { transfer }\end{array}$ & + & \\
\hline Tanganyika aningre & & [155] & 3 & & $100 \%+$ & $100 \%-$ & $\begin{array}{l}100 \%- \\
\text { precipitin }\end{array}$ & $100 \%+$ & \\
\hline $\begin{array}{l}\text { Central American walnut } \\
\text { (Juglans olanchana) }\end{array}$ & & [156] & 1 & & - & - & precipitin & + & \\
\hline Kejaat (Pterocarpus ango & olensis) & [157] & 1 & & + & ND & ND & ND & \\
\hline $\begin{array}{l}\text { African zebrawood } \\
\text { (Microberlinia) }\end{array}$ & & [158] & 1 & & + & + & ND & + & \\
\hline $\begin{array}{l}\text { Ramin } \\
\quad \text { (Gonystylus bancanus) }\end{array}$ & Woodworker & [159] & 2 & & + & + & ND & + & \\
\hline Quillaja bark & $\begin{array}{l}\text { Factory to produce } \\
\text { Saponin }\end{array}$ & {$[160]$} & 1 & & ND & + & ND & + & \\
\hline $\begin{array}{l}\text { Fernambouc } \\
\quad \text { (Caesalpinia echinata) }\end{array}$ & Bow-making & {$[161]$} & 36 & 33.3 & $100 \%-$ & ND & ND & $100 \%$ of $1+$ & \\
\hline $\begin{array}{l}\text { Ashwood } \\
\quad \text { (Fraxinus americana) }\end{array}$ & Sawmill & {$[162]$} & 1 & & - & - & ND & + & \\
\hline
\end{tabular}

For abbreviations see beginning of table. References are placed at the end of the table. 
Table 1. continued

\begin{tabular}{|c|c|c|c|c|c|c|c|c|c|}
\hline Agents & Occupation & [Ref] & $\begin{array}{c}\text { Subjects } \\
\mathrm{n}\end{array}$ & $\begin{array}{c}\text { Prevalence } \\
\%\end{array}$ & $\begin{array}{c}\text { Skin } \\
\text { test }\end{array}$ & Specific IgE & $\begin{array}{c}\text { Other } \\
\text { immunologic }\end{array}$ & $\begin{array}{l}\text { Broncho- } \\
\text { provocation } \\
\text { test }\end{array}$ & $\begin{array}{c}\text { Other } \\
\text { evidence }\end{array}$ \\
\hline \multicolumn{10}{|l|}{ Pau Marfim } \\
\hline $\begin{array}{l}\text { (Balfourodendron } \\
\text { riedelianum) }\end{array}$ & Wood-worker & [163] & 1 & NA & + & + & ND & + & ND \\
\hline \multicolumn{10}{|l|}{ Capreuva } \\
\hline $\begin{array}{l}\text { (Myyrocarpus } \\
\text { fastigiatus Fr. All.) }\end{array}$ & Parquet floor layer & {$[164]$} & 1 & NA & ND & ND & ND & + & ND \\
\hline $\begin{array}{l}\text { Eastern white cedar } \\
\quad \text { (Thuja occidentalis) }\end{array}$ & Sawmill & {$[165]$} & 1 & & ND & - & ND & + & $\begin{array}{l}\text { PEFR } \\
\text { recording }\end{array}$ \\
\hline $\begin{array}{l}\text { Ebony wood } \\
\quad \text { (Diospyros crassiflora }\end{array}$ & & [166] & 1 & & - & ND & ND & + & \\
\hline $\begin{array}{l}\text { Kotibe wood } \\
\quad \text { (Nesorgordonia papve }\end{array}$ & eifera) & [167] & 1 & & + & ND & $\begin{array}{l}\text { Passive } \\
\text { transfer }\end{array}$ & + & \\
\hline $\begin{array}{l}\text { Cinnamon } \\
\quad \text { (Cinnamomum zeylani }\end{array}$ & icum) & {$[168]$} & 40 & 22.5 & ND & ND & ND & $100 \%$ of $1+$ & \\
\hline$?$ & $\begin{array}{l}\text { Sawmills of } \\
\text { Eastern Canada } \\
\text { and USA }\end{array}$ & [169] & 11 & ND & ND & ND & ND & $\begin{array}{c}+ \\
\text { PEFR } \\
\text { monitoring }\end{array}$ & \\
\hline \multicolumn{10}{|l|}{ Metals } \\
\hline \multirow[t]{2}{*}{ Platinum } & Platinum & {$[170]$} & 16 & & $62 \%+$ & ND & ND & $62 \%+$ & \\
\hline & refinery & {$[171]$} & 136 & 29 & $17 \%+$ & $21 \%+$ & ND & ND & \\
\hline \multirow[t]{3}{*}{ Nickel } & Metal plating & {$[172]$} & 1 & & + & ND & $\begin{array}{c}- \\
\text { precipitin }\end{array}$ & + & \\
\hline & & [173] & 1 & & + & ND & $\begin{array}{c}- \\
\text { precipitin }\end{array}$ & + & \\
\hline & & {$[174]$} & 1 & & + & + & ND & + & \\
\hline \multirow[t]{2}{*}{ Cobalt } & Hard metal grinders & {$[175]$} & 4 & & $25 \%+$ & ND & ND & $50 \%+$ & \\
\hline & Diamond polisher & [176] & 3 & & ND & ND & ND & $100 \%+$ & \\
\hline \multirow[t]{2}{*}{ Zinc fumes } & Solderers & {$[177]$} & 2 & & ND & ND & ND & + & \\
\hline & Locksmith & {$[178]$} & 1 & & ND & ND & ND & + & \\
\hline Tungsten carbide & Grinder & [179] & 1 & & ND & ND & ND & ND & $\begin{array}{l}\text { Recovery on } \\
\text { removal }\end{array}$ \\
\hline \multirow[t]{2}{*}{ Chromium } & Printer & {$[180]$} & 1 & & + & ND & ND & ND & \\
\hline & Plater & {$[181]$} & 1 & & + & ND & ND & ND & \\
\hline \multirow[t]{2}{*}{ Chromium and nickel } & Welder & {$[182]$} & 5 & & ND & ND & ND & $100 \%$ of $2+$ & \\
\hline & Tanning & {$[183]$} & 1 & & - & + & ND & + & \\
\hline \multirow[t]{2}{*}{ Cobalt and nickel } & & [184] & 8 & & $\begin{array}{l}75 \%+ \\
\text { cobalt }\end{array}$ & $\begin{array}{l}62 \%+ \\
\text { cobalt }\end{array}$ & ND & $100 \%$ + to both & \\
\hline & & & & & $\begin{array}{l}62 \%+ \\
\text { nickel }\end{array}$ & $\begin{array}{l}50 \%+ \\
\text { nickel }\end{array}$ & ND & cobalt and nickel & \\
\hline \multicolumn{10}{|l|}{ Drugs } \\
\hline $\begin{array}{l}\text { Penicillins and } \\
\text { ampicillin }\end{array}$ & Pharmaceutical & [185] & 4 & & $100 \%-$ & ND & ND & $75 \%+$ & \\
\hline Penicillamine & Pharmaceutical & {$[186]$} & 1 & & ND & - & ND & + & PEFR recording \\
\hline \multirow{2}{*}{ Cephalosporins } & Pharmaceutical & [187] & 2 & & + & ND & ND & + & \\
\hline & Pharmaceutical & [188] & 91 & 7.7 & $7.1 \%+$ & ND & ND & ND & $\begin{array}{l}\text { Improvement } \\
\text { off-work }\end{array}$ \\
\hline $\begin{array}{l}\text { Phenylglycine acid } \\
\text { chloride }\end{array}$ & Pharmaceutical & [189] & 24 & 29 & $37 \%+$ & $37 \%+$ & $\begin{array}{l}\text { Passive } \\
\text { transfer }\end{array}$ & $100 \%$ of $2+$ & \\
\hline \multirow[t]{4}{*}{ Psyllium } & Laxative manuf. & [190] & 3 & & $100 \%+$ & ND & ND & $60 \%+$ & \\
\hline & Pharmaceutical & [191] & 130 & $4 * 19 \% \mathrm{o}$ & of $120+26 \%$ of $118+$ & ND & $27 \%$ of $18+$ & & \\
\hline & Nurses & {$[192]$} & 5 & & $80 \%+$ & $100 \%+$ & ND & $100 \%+$ & \\
\hline & Health personnel & [193] & 193 & $4^{*}$ & $3 \%+$ & $12 \%$ of $162+$ & ND & $26 \%$ of $15+$ & \\
\hline Methyl dopa & Pharmaceutical & [194] & 1 & & - & ND & ND & + & \\
\hline \multirow{3}{*}{ Spiramycin } & Pharmaceutical & [195] & 1 & & + & ND & ND & + & \\
\hline & Pharmaceutical & [196] & 51 & $7.8^{*}$ & $100 \%-$ & ND & ND & $25 \%$ of $12+$ & \\
\hline & Pharmaceutical & [197] & 2 & & ND & - & ND & + & \\
\hline $\begin{array}{l}\text { Salbutamol } \\
\text { intermediate }\end{array}$ & Pharmaceutical & [198] & 1 & & - & ND & ND & + & \\
\hline Amprolium & Poultry feed mixer & [199] & 1 & & ND & ND & ND & + & \\
\hline \multirow[t]{2}{*}{ Tetracycline } & Pharmaceutical & {$[200]$} & 1 & & ND & ND & ND & + & \\
\hline & Pharmaceutical & [201] & 1 & & + & ND & ND & + & \\
\hline $\begin{array}{l}\text { Isonicotinic acid } \\
\text { hydrazide }\end{array}$ & Hospital pharmacy & [202] & 1 & & + & + & ND & + & \\
\hline Hydralazine & Pharmaceutical & [203] & 1 & & - & - & $\begin{array}{c}- \\
\text { Specific } \mathrm{IgG}\end{array}$ & + & \\
\hline Tylosin tartrate & Pharmaceutical & [204] & 1 & & ND & ND & ND & _- & \\
\hline Ipecacuanha & Pharmaceutical & {$[205]$} & 42 & 47.6 & $52 \%$ of $19+$ & $66 \%$ of $18+$ & ND & ND & \\
\hline Cimetidine & Pharmaceutical & [206] & 4 & & ND & ND & ND & $25 \%+$ & \\
\hline Opiate compounds & Pharmaceutical & [207] & 39 & $26 \%$ & + & ND & ND & ND & $\begin{array}{c}\text { PEFR } \\
\text { pre-post shift } \\
\text { FEV }_{1}\end{array}$ \\
\hline
\end{tabular}

For abbreviations beginning end of table. References are placed at the end of the table. 


\begin{tabular}{|c|c|c|c|c|c|c|c|c|c|}
\hline Agents & Occupation & {$[\operatorname{Ref}]$} & $\begin{array}{c}\text { Subjects } \\
\mathrm{n}\end{array}$ & $\begin{array}{c}\text { Prevalence } \\
\%\end{array}$ & $\begin{array}{l}\text { Skin } \\
\text { test }\end{array}$ & Specific IgE & $\begin{array}{c}\text { Other } \\
\text { immunologic }\end{array}$ & $\begin{array}{l}\text { Broncho- } \\
\text { provocation } \\
\text { test }\end{array}$ & $\begin{array}{c}\text { Other } \\
\text { evidence }\end{array}$ \\
\hline \multicolumn{10}{|l|}{ Chemicals } \\
\hline \multirow[t]{3}{*}{ Chloramine $\mathrm{T}$} & Chemical manuf. & [208] & 6 & & $100 \%+$ & ND & $\begin{array}{c}66 \%+ \\
\text { passive transfer }\end{array}$ & ND & \\
\hline & Brewery & [209] & 7 & & $100 \%+$ & ND & ND & ND & $\begin{array}{l}\text { Recovery with } \\
\text { removal }\end{array}$ \\
\hline & Janitor-cleaning & {$[210]$} & 5 & & $100 \%$ of $4+$ & ND & ND & $100 \%$ of $3+$ & \\
\hline \multirow{3}{*}{$\begin{array}{l}\text { Polyvinyl chloride } \\
\text { (fumes) } \\
\text { (powder) }\end{array}$} & Meat wrapper & {$[211]$} & 96 & 69.0 & ND & ND & ND & $27 \%$ of $11+$ & \\
\hline & Meat wrapper & {$[212]$} & 3 & & ND & ND & ND & ND & History only \\
\hline & Manuf. bottle caps & [213] & 1 & & ND & ND & ND & + & PEFR recording \\
\hline $\begin{array}{l}\text { Ethylcyanoacrylate } \\
\text { ester }\end{array}$ & $\begin{array}{l}\text { Building airplane } \\
\text { models }\end{array}$ & [214] & 1 & & ND & ND & ND & + & \\
\hline $\begin{array}{l}\text { Organic phosphate } \\
\text { insecticides }\end{array}$ & $\begin{array}{l}\text { Chemical pack- } \\
\text { aging plant }\end{array}$ & [215] & 1 & & ND & ND & ND & ND & History only \\
\hline $\begin{array}{l}\text { Levafix brilliant } \\
\text { yellow E36 }\end{array}$ & Pre dye solution & [216] & 1 & & + & ND & ND & + & \\
\hline \multicolumn{10}{|l|}{ Drimaren brilliant } \\
\hline Yellow K-3GL & Textile industry & [216] & 1 & & + & ND & ND & + & \\
\hline $\begin{array}{l}\text { Cibachrome brilliant } \\
\text { scarlet } 32\end{array}$ & Textile industry & [216] & 1 & & + & ND & $\begin{array}{c}\text { ND } \\
\text { Evidence }\end{array}$ & $\begin{array}{c}+ \\
\text { Test }\end{array}$ & \\
\hline $\begin{array}{l}\text { Drimaren brilliant } \\
\text { blue K-BL }\end{array}$ & Textile industry & [216] & 1 & & + & ND & ND & + & \\
\hline \multirow[t]{2}{*}{ Reactive dyes } & $\begin{array}{l}\text { Reactive dyes } \\
\text { manufacture }\end{array}$ & [217] & 309 & 25.2 & $\begin{array}{c}7 \%+ \\
\text { orange }\end{array}$ & $\begin{array}{l}17 \%+ \\
\text { orange }\end{array}$ & ND & $65 \%$ of $20+$ & \\
\hline & & & & $\begin{array}{l}8 \%+ \\
\text { black }\end{array}$ & $\begin{array}{l}17 \%+ \\
\text { black }\end{array}$ & & & & \\
\hline Lanasol yellow 4G & Dyer & [218] & 1 & NA & + & ND & ND & + & \\
\hline \multirow{5}{*}{$\begin{array}{l}\text { Persulphate salts } \\
\text { \& henna }\end{array}$} & Hairdressing & [219] & 2 & & + & ND & ND & + & \\
\hline & Hairdressing & [220] & 2 & & + & ND & ND & + & \\
\hline & Hairdressing & [221] & 23 & 17.4 & $4 \%+$ & ND & ND & $100 \%$ of $4+$ & \\
\hline & Hairdressing & [222] & 1 & & - & ND & ND & + & \\
\hline & Hairdressing & [223] & 1 & & ND & ND & ND & + & \\
\hline \multirow[t]{3}{*}{$\begin{array}{l}\text { Azodicarbonamide } \\
\quad \text { (azobisformamide) }\end{array}$} & Plastics, rubber & [224] & 151 & 18.5 & ND & ND & ND & ND & $\begin{array}{l}\text { Removal with } \\
\text { improvement }\end{array}$ \\
\hline & Plastic & [225] & 2 & & ND & ND & ND & + & \\
\hline & Plastics & {$[226]$} & 4 & & ND & ND & ND & $100 \%$ of $2+$ & \\
\hline \multirow[t]{2}{*}{ Diazonium salt } & $\begin{array}{l}\text { Manuf. of photocopy } \\
\text { paper }\end{array}$ & [227] & 1 & & ND & ND & ND & + & \\
\hline & $\begin{array}{l}\text { Manuf. of fluorine } \\
\text { polymer precursor }\end{array}$ & [228] & 45 & 55.5 & ND & $20 \%+$ & ND & $100 \%$ of 2 & \\
\hline $\begin{array}{l}\text { Hexachlorophene } \\
\text { (sterilizing agent) }\end{array}$ & Hospital staff & [229] & 1 & & ND & ND & ND & + & \\
\hline \multirow[t]{3}{*}{ Formaldehyde } & Hospital staff & {$[230]$} & 28 & $29 *$ & ND & ND & ND & $50 \%$ of $4+$ & \\
\hline & Different indust. & [231] & 15 & & ND & ND & ND & $60 \%+$ & \\
\hline & & [232] & 230 & 5.2 & ND & ND & ND & $5 \%+$ & \\
\hline \multirow[t]{2}{*}{ Urea formaldehyde } & Resin & [233] & 2 & & - & ND & ND & + & \\
\hline & Manuf. of foam & {$[234]$} & 1 & & ND & ND & ND & + & \\
\hline Freon & Refrigeration & {$[235]$} & 1 & & ND & ND & ND & + & \\
\hline \multirow{3}{*}{$\begin{array}{l}\text { Furfuryl alcohol } \\
\text { (furan based resin) }\end{array}$} & Foundry mold & & & & & & & & \\
\hline & making & [236] & 1 & & ND & ND & ND & + & \\
\hline & Wool dye house & {$[237]$} & 6 & & ND & $83 \%+$ & $100 \%+$ & ND & \\
\hline Styrene & Plastics factory & [238] & 2 & & - & ND & ND & + & \\
\hline Glutaraldehyde & $\begin{array}{l}\text { Hospital endoscopy } \\
\text { unit }\end{array}$ & [239] & 9 & 88.8 & ND & ND & ND & ND & Questionnaire \\
\hline \multirow{2}{*}{$\begin{array}{l}\text { Methyl methacrylate } \\
\text { and cyanocrylates }\end{array}$} & Adhesive & {$[240]$} & 7 & & ND & ND & ND & $86 \%+$ & PEFR 14\% + \\
\hline & Nurse & {$[241]$} & 1 & & ND & ND & ND & + & \\
\hline \multicolumn{10}{|c|}{ oxybenzene sulphonate } \\
\hline Chlorhexidine & Nurse & [243] & 2 & & ND & ND & ND & + & \\
\hline Tetrazene & Detonator manuf. & [244] & 1 & & ND & ND & ND & + & $\begin{array}{l}+ \text { PEFR } \\
\text { recording }\end{array}$ \\
\hline Ethylene dioxide & Nurse & [245] & 1 & NA & ND & + & ND & + & $\begin{array}{l}\text { Changes in } \\
\text { PC }_{20}\end{array}$ \\
\hline Polyethylene & Paper packer & [246] & 1 & NA & ND & ND & ND & + & $\begin{array}{c}+ \text { PEFR } \\
\text { recording }\end{array}$ \\
\hline $\begin{array}{l}\text { Tetracholoro- } \\
\text { isophthalonitrile } \\
\text { (fungicide) }\end{array}$ & Farmer & [247] & 1 & NA & ND & - & + patch test & + & $\begin{array}{c}\mathrm{FEV}_{1} \text { recording } \\
\text { at work }\end{array}$ \\
\hline $\begin{array}{l}\text { Tributyl tin oxide } \\
\text { (fungicide) }\end{array}$ & $\begin{array}{c}\text { Venipuncture } \\
\text { technician }\end{array}$ & [248] & 1 & NA & - & ND & ND & + & \\
\hline $\begin{array}{l}\text { Tall oil } \\
\quad \text { (pine resin) }\end{array}$ & $\begin{array}{l}\text { Rubber tyre } \\
\text { manufacturer }\end{array}$ & [249] & 1 & NA & - & ND & -patch test & + & $\begin{array}{l}+ \text { PEFR } \\
\text { recording }\end{array}$ \\
\hline
\end{tabular}


Table 1. continued

\begin{tabular}{|c|c|c|c|c|c|c|c|c|c|}
\hline Agents & Occupation & [Ref] & $\begin{array}{c}\text { Subjects } \\
\mathrm{n}\end{array}$ & $\begin{array}{c}\text { Prevalence } \\
\%\end{array}$ & $\begin{array}{l}\text { Skin } \\
\text { test }\end{array}$ & Specific IgE & $\begin{array}{c}\text { Other } \\
\text { immunologic }\end{array}$ & $\begin{array}{l}\text { Broncho- } \\
\text { provocation } \\
\text { test }\end{array}$ & $\begin{array}{c}\text { Other } \\
\text { evidence }\end{array}$ \\
\hline Plexiglass & & [250] & 1 & & ND & ND & ND & + & \\
\hline Latex & Glove manuf. & [251] & 81 & 6 & $11 \%+$ & ND & ND & ND & $\begin{array}{l}\text { PEFR recording. } \\
\text { Pre-post shift } \\
\text { change in } \mathrm{FEV}_{1}\end{array}$ \\
\hline \multicolumn{10}{|l|}{ Unidentified } \\
\hline (?) & $\begin{array}{l}\text { Mineral analysis } \\
\text { laboratory }\end{array}$ & [253] & 21 & $23.8^{*}$ & ND & ND & ND & ND & $\begin{array}{l}\text { Questionnaire } \\
\qquad \mathrm{PC}_{20}\end{array}$ \\
\hline (?) Oil mists & Toolsetter & [254] & 1 & & ND & ND & ND & + & PEFR recording \\
\hline (?) Fluorine & Potroom & [255] & 52 & & ND & ND & ND & ND & History \\
\hline \multirow[t]{3}{*}{ (?) Aluminum } & Potroom & [256] & 227 & 7.0 & ND & ND & ND & ND & Questionnaire \\
\hline & Potroom & [257] & 35 & & ND & ND & ND & ND & History \\
\hline & Potroom & [258] & 57 & & ND & ND & ND & ND & History \\
\hline
\end{tabular}

For abbreviations beginning end of table. References are placed at the end of the table.

\section{Table References}

1. Venables KM, Tee RD, Hawkins ER, et al. Laboratory animal allergy in a pharmaceutical company. $\mathrm{Br} J$ Ind Med 1988; 45: 660-666.

2. Newman-Taylor AJ, Longbottom JL, Pepys J. Respiratory allergy to urine proteins of rats and mice. Lancet 1977; 847-849.

3. Mäntyjärvi J, Ylönen R, Taivainen A, Virtanen T. IgG and IgE antibody responses to cow dander and urine in farmers with cow-induced asthma. Clin Exp Allergy 1992; 22: 83-90.

4. Bar-Sela S, Teichtahl H, Lutsky I. Occupational asthma in poultry workers. J Allergy Clin Immunol 1984; 73: 271-275.

5. Lutsky I, Teichtahl H, Bar-Sela S. Occupational asthma due to poultry mites. J Allergy Clin Immunol 1984; 73: $56-60$.

6. Brennan NJ. Pig Butcher's asthma: case report and review of the literature. Irish Med J 1985; 78: 321-322.

7. Armentia A, Martin-Santos J, Subiza J, et al. Occupational asthma due to frogs. Ann Allergy 1988; 60: 209-210.

8. Moneret-Vautrin DA, Pupil P, Courtine D, Grilliat JP. Asthme professionnel aux protéines du lactosérum. Rev Fr Allergol 1984; 24: 93-95.

9. Olaguibel JM, Hernandez D, Morales P, Peris A, Basomba A. Occupational asthma caused by inhalation of casein. Allergy 1990; 45: 306-308.

10. El-Ansary EH, Gordon DJ, Tee RD, Newman-Taylor AJ. Respiratory allergy to inhaled bat guano. Lancet 1987; i: $316-318$.

11. Cuthbert OD, Jeffrey IG, McNeill HB, Wood J, Topping MD. Barn allergy among Scottish farmers. Clin Allergy 1984; 14: 197-206.

12. Blainey AD, Topping MD, Ollier S, Davies RJ. Allergic respiratory disease in grain workers: the role of storage mites. J Allergy Clin Immunol 1989; 84: 296-303.

13. Burge PS, Edge G, O'Brien IM, Harries MG, Hawkins R, Pepys J. Occupational asthma in a research centre breeding locusts. Clin Allergy 1980; 10: 355-363.

14. Tee RD, Gordon DJ, Hawkins ER, et al. Occupational allergy to locusts: an investigation of the sources of the allergen. J Allergy Clin Immunol 1988; 81: 517-525.

15. Gibbons HL, Dille JR, Cowley RG. Inhalant allergy to the screw worm fly. Arch Environ Health 1965; 10 : 424-430.
16. Bagenstose AH, Mathews KP, Homburger HA, SaaveardDelgado AP. - Inhalant allergy due to crickets. J Allergy Clin Immunol 1980; 65: 71-74.

17. Stevenson DD, Mathews KP. Occupational asthma following inhalation of moth particles. J Allergy 1967; 39: 274-283.

18. Randolph H. Allergic reaction to dust of insect origin. J Am Med Assoc 1934; 103: 560-562.

19. Wittich FW. Allergic rhinitis and asthma due to sensitization to the Mexican bean weevil (Zabrotes subfasciatus boh.). J Allergy 1940; 12: 42-45.

20. Spieksma FTM, Vooren PH, Kramps JA, Dijkman JH. Respiratory allergy to laboratory fruit flies (Drosophila melanogaster). J Allergy Clin Immunol 1986; 77: 108-113.

21. Ostrom NK, Swanson MC, Agarwal MK, Yunginger JW. Occupational allergy to honeybee-body dust in a honeyprocessing plant. J Allergy Clin Immunol 1986; 77 : 736-740.

22. Siracusa A, Verga A, Bacoccoli R, Fabbri A, Felicioni D. L'asma da bigattini (Larve della mosca camaria): studio clinico e immunologico. Med Lav 1989; 80: 489-497.

23. Schroeckenstein DC, Meier-Davis S, Graziano FM, Falomo A, Bush RK. Occupational sensitivity to Alphitobius diaperinus (Panzer) (lesser mealworm). J Allergy Clin Immunol 1988; 82:1081-1088.

24. Lutsky I, Bar-Sela S. Northern fowl mite (Ornithonyssus sylvianum) in occupational asthma of poultry workers. Lancet 1982; 2: 874-875.

25. Cuthbert OD, Brostoff J, Wraith DG, Brighton WD. "Barn allergy": asthma and rhinitis due to storage mites. Clin Allergy 1979; 9: 229-236.

26. Granel-Tena C, Cistero-Bahima A, Olive-Perez A. Allergens in asthma and baker's rhinitis. Alergia 1985; 32: 69-73.

27. Michel FB, Guin JJ, Seignalet $\mathrm{C}$, et al. Allergie à Panonychus ulmi (Koch). Rev Fr Allergol 1977; 17: 93-97.

28. Meister W. Professional asthma owing to Daphnia allergy. Allerg Immunol (Leipz) 1978; 24: 191-193.

29. Axelsson IGK, Johansson SGO, Zetterstrom O. Occupational allergy to weeping fig in plant keepers. Allergy 1987; 42: 161-167.

30. Kaufman GL, Gandevia BH, Bellas TE, Tovey ER, Baldo BA. Occupational allergy in an entomological research centre. I. Clinical aspects of reactions to the sheep blowfly Lucilia cuprina. Br J Ind Med 1989; 46: 473-478. 
31. Uragoda CG, Wijekoon PMB. Asthma in silk workers. J Soc Occup Med 1991; 41: 140-142.

32. Chan-Yeung M, Schulzer M, MacLean L, Dorken E, Grzybowski S. Epidemiologic health survey of grain elevator workers in British Columbia. Am Rev Respir Dis 1980; 121: 329-338.

33. Williams N, Skoulas A, Merriman JE. Exposure to grain dust. I. A survey of the effects. J Occup Med 1964; 6: 319-329.

34. Skoulas A, Williams N, Merriman JE. Exposure to grain dust. II. A clinical study of the effects. J Occup Med 1964; 6: 359-372.

35. Chan-Yeung M, Wong R, MacLean L. Respiratory abnormalities among grain elevator workers. Chest 1979; 75: 461-467.

36. Musk AW, Venables KM, Crook B, et al. Respiratory symptoms, lung function, and sensitisation to flour in a British bakery. Br J Ind Med 1989; 46: 636-642.

37. Block G, Tse KS, Kijek K, Chan H, Chan-Yeung M. Baker's asthma. Clin Allergy 1983; 13: 359-370.

38. Sutton R, Skerritt JH, Baldo BA, Wrigley CW. The diversity of allergens involved in baker's asthma. Clin Allergy 1984; 14: 93-107.

39. Valdivieso R, Quirce S, Sainz T. Bronchial asthma caused by Lathyrus sativus flour. Allergy 1988; 43: 536-539.

40. Picon SJ, Carmona JGB, Sotillos MDMG. Occupational asthma caused by vetch (Vicia sativa). J Allergy Clin Immunol 1991; 88: 135-136.

41. Ordman D. Buckwheat allergy. S Afr Med J 1947; 21: 737-739.

42. Lachance P, Cartier A, Dolovich J, Malo J-L. Occupational asthma from reactivity to an alkaline hydrolysis derivative of gluten. J Allergy Clin Immunol 1988; 81: 385390.

43. Jones RN, Hughes JM, Lehrer SB, et al. Lung function consequences of exposure and hypersensitivity in workers who process green coffee beans. Am Rev Respir Dis 1982; 125: 199-202.

44. Zuskin E, Valic F, Kanceljak B. Immunological and respiratory changes in coffee workers. Thorax 1981; 36: 9-13.

45. Osterman K, Johansson SGO, Zetterstrom O. Diagnostic tests in allergy to green coffee. Allergy 1985; 40: 336-343.

46. Panzani R, Johansson SGO. Results of skin test and RAST in allergy to a clinically potent allergen (castor bean). Clin Allergy 1986; 16: 259-266.

47. Cartier A, Malo JL. Occupational asthma due to tea dust. Thorax 1990; 45: 203-206.

48. Blanc PD, Trainor WD, Lim DT. Herbal tea asthma. Br J Ind Med 1986; 43: 137-138.

49. Gleich GJ, Welsh PW, Yunginger JW, Hyatt RE, Catlett JB. Allergy to tobacco: an occupational hazard. $N$ Engl $J$ Med 1980; 302: 617-619.

50. Lander F, Gravesen S. Respiratory disorders among tobacco workers. Br J Ind Med 1988; 45: 500-502.

51. Newmark FM. Hops allergy and terpene sensitivity: an occupational disease. Ann Allergy 1978; 41: 311-312.

52. Twiggs JT, Yunginger JW, Agarwal MK, Reed CE. Occupational asthma in a florist caused by the dried plant, baby's breath. J Allergy Clin Immunol 1982; 69: 474-477.

53. van Toorenenbergen AW, Dieges PH. Occupational allergy in horticulture: demonstration of immediate-type allergic reactivity to freesia and paprika plants. Int Arch Allergy Appl Immunol 1984; 75: 44-47.

54. Symington IS, Kerr JW, McLean DA. Type I allergy in mushroom soup processors. Clin Allergy 1981; 11: 4347.
55. Rubin JM, Duke MB. Unusual cause of bronchial asthma. Cacoon seed used for decorative purposes. NY State J Med 1974; 74 (3): 538-539.

56. Nemery B, Demedts M. Occupational asthma in a chicory grower. Lancet 1989; i: 672-673.

57. Kwaselow A, Rowe M, Sears-Ewald D, Ownby D. Rose hips: a new occupational allergen. J Allergy Clin Immunol 1990; 85: 704-708.

58 Bousquet OJ, Dhivert H, Clauzel AM, Hewitt B, Michel FB. Occupational allergy to sunflower pollen. $J$ Allergy Clin Immunol 1985; 75: 70-75.

59. Falleroni AE, Zeiss CR, Levitz D. Occupational asthma secondary to inhalation of garlic dust. J Allergy Clin Immunol 1981; 68: 156-160.

60. Lybarger JA, Gallagher JS, Pulver DW, Litwin A, Brooks $\mathrm{S}$, Bernstein IL. Occupational asthma induced by inhalation and ingestion of garlic. J Allergy Clin Immunol 1982; 69: 448-454.

61. Catilina P, Chamoux A, Gabrillargues D, Catilina MJ, Royfe MH, Wahl D. Contribution à l'étude des asthmes d'origine professionnelle: l'asthme à la poudre de lycopode. Arch Mal Prof 1988; 49: 143-148.

62. Charpin J, Blanc M. Une cause nouvelle d'allergie professionnelle chez les coiffeuses: l'allergie à la séricine. Marseille Médical 1967; 104: 169-170.

63. Zedda S. A case of bronchial asthma from inhalation of nacre dust. Med Lav 1967; 58: 459-464.

64. Kraut A, Peng Z, Becker AB, Warren CPW. Christmas candy maker's asthma. $\mathrm{IgG}_{4}$-mediated pectin allergy. Chest 1992; 102: 1605-1607.

65. Starr JC, Yunginger J, Brahser GW. Immediate type I asthmatic response to henna following occupational exposure in hairdressers. Ann Allergy 1982; 48: 98-99.

66. Côté J, Chan H, Brochu G, Chan-Yeung M. Occupational asthma caused by exposure to neurospora in a plywood factory worker. Br J Ind Med 1991; 48: 279-282.

67. Juniper CP, How MJ, Goodwin BFJ. Bacillus subtilis enzymes: a 7-year clinical, epidemiological and immunological study of an industrial allergen. J Soc Occup Med 1977; 27: 3-12.

68. Franz T, McMurrain KD, Brooks S, Bernstein IL. Clinical, immunologic and physiologic observations in factory workers exposed to $B$. subtilis enzyme dust. $J$ Allergy 1971; 47: 170-179.

69. Colten HR, Polakoff PL, Weinstein SF, Strieder DJ. Immediate hypersensitivity to hog trypsin resulting from industrial exposure. N Engl J Med 1975; 292: 1050-1053.

70. Baur X, Konig G, Bencze K, Fruhmann G. Clinical symptoms and results of skin test, RAST and bronchial provocation test in thirty three papain workers: evidence for strong immunogenic potency and clinically relevant "proteolytic effects of airborne papain". Clin Allergy 1982; 12: 9-17.

71. Cartier A, Malo J-L, Pineau L, Dolovich J. Occupational asthma due to pepsin. J Allergy Clin Immunol 1984; 73 : 574-577.

72. Wiessmann KJ, Baur X. Occupational lung disease following long-term inhalation of pancreatic extracts. Eur J Respir Dis 1985; 66: 13-20.

73. Pauwels R, Devos M, Callens L, Van der Straeten M. Respiratory hazards from proteolytic enzymes. Lancet 1978; i: 669.

74. Cortona G, Beretta F, Traina G, Nava C. Preliminary investigation in a pharmaceutical industry: bromelininduced pathology. Med Lav 1980; 1: 70-75.

75. Galleguillos F, Rodriguez JC. Asthma caused by bromelin inhalation. Clin Allergy 1978; 8: 21-24. 
76. Bernstein JA, Kraut A, Bernstein Dl, Warrington R, Bolin T, Warren CPW. Occupational asthma induced by inhaled egg lysozyme. Chest 1993; 103: 532-535.

77. Baur X, Fruhmann G, Haug B, Rasche B, Reiher W, Weiss W. Role of Aspergillus amylase in baker's asthma. Lancet 1986; i: 43.

78. Bimbaum J, Latil F, Vervloet D, Senft M, Charpin J. Rôle de l'alpha-amylase dans l'asthme du boulanger. Rev Mal Respir 1988; 5: 519-521.

79. Baur X, Weiss W, Sauer W, et al. Baking components as a contributory cause of baker's asthma. Dtsch Med Wschr 1988; 113: 1275-1278.

80. Zachariae H, Høegh-Thomsen J, Witmeur O, Wide L. Detergent enzymes and occupational safety. Observations on sensitization during Esperase ${ }^{\circledR}$ production. Allergy 1981; 36: 513-516.

81. Fowler PBS. Printer's asthma. Lancet 1952; ii: 755-757.

82. Bohner CB, Sheldon JM, Trenis JW. Sensitivity to gum acacia, with a report of ten cases of asthma in printers. J Allergy 1941; 12: 290-294.

83. Gelfand HH. The allergenic properties of vegetable gums: a case of asthma due to tragacanth. J Allergy 1943; 14: 203-219.

84. Feinberg SM, Schoenkerman BB. Karaya and related gums as causes of atopy. Wisconsin Med J 1940; 39: 734.

85. Malo JL, Cartier A, L'Archevêque J, et al. Prevalence of occupational asthma and immunological sensitization to guar gum among employees at a carpet-manufacturing plant. J Allergy Clin Immunol 1990; 86: 562-569.

86. Cartier A, Malo JL, Forest F, et al. Occupational asthma in snow-crab processing workers. $J$ Allergy Clin Immunol 1984; 74: 261-269.

87. Gaddie J, Legge JS, Friend JAR, Reid TMS. Pulmonary hypersensitivity in prawn workers. Lancet 1980; ii: 1350-1353.

88. Jyo T, Kohmoto K, Katsutani T, Otsuka T, Oka SD, Mitsui S. Hoya (sea-squirt) asthma. Occupational Asthma. London, Von Nostrand Reinhold, 1980; pp. 209-228.

89. Tomaszunas S, Weclawik Z, Lewinski M. Allergic reactions to cuttlefish in deep-sea fishermen. Lancet 1988; i: 1116-1117.

90. Sherson D, Hansen I, Sigsgaard T. Occupationallyrelated respiratory symptoms in trout-processing workers. Allergy 1989; 44: 336-341.

91. Carino M, Elia G, Molinini R, Nuzzaco A, Ambrosi L. Shrimp meal asthma in the aquaculture industry. Med Lav 1985; 76: 471-475.

92. Kobayashi S. Different aspects of occupational asthma in Japan. Occupational asthma. In: Frazier CA, ed. New York, Van Nostrand Reinhold Co. 1980; pp. 229244.

93. Smith AB, Bernstein DI, London MA, et al. Evaluation of occupational asthma from airborne egg protein exposure in multiple settings. Chest 1990; 98: 398-404.

94. Resta O, Foschino-Barbaro MP, Carnimeo N, Napoli PL Di, Pavese I, Schino P. Occupational asthma from fishfeed. Med Lav 1982; 3: 234-236.

95. Onizuka R, Inoue K, Kamiya H. Red soft coral-induced allergic symptoms observed in spiny lobster fishermen. Aerugi 1990; 39: 339-347.

96. Butcher BT, Salvaggio JE, Weill H, Ziskind MM. Toluene diisocyanate (TDI) pulmonary disease: immunologic and inhalation challenge studies. J Allergy Clin Immunol 1976; 58: 89-100.

97. Butcher BT, O'Neil CE, Reed MA, Salvaggio JE. Radioallergosorbent testing of toluene diisocyanate-reac- tive individuals using p-tolyl isocyanate antigen. $J$ Allergy Clin Immunol 1980; 66: 213-216.

98. Baur X, Fruhmann G. Specific IgE antibodies in patients with isocyanate asthma. Chest 1981; 80: 73S-76S.

99. Paggiaro PL, Filieri M, Loi AM, et al. Absence of IgG antibodies to TDI-HSA in a radioimmunological study. Clin Allergy 1983; 13: 75-79.

100. Mapp CE, Boschetto P, Dal Vecchio L, Maestrelli P, Fabbri LM. Occupational asthma due to isocyanates. Eur Respir J 1988; 1: 273-279.

101. Zammit-Tabona M, Sherkin M, Kijek K, Chan H, ChanYeung M. Asthma caused by diphenylmethane diisocyanate in foundry workers. Clinical, bronchial provocation, and immunologic studies. Am Rev Respir Dis 1983; 128: 226-230.

102. Tse KS, Johnson A, Chan H, Chan-Yeung M. A study of serum antibody activity in workers with occupational exposure to diphenylmethane diisocyanate. Allergy 1985; 40: 314-320.

103. Liss GM, Bernstein DI, Moller DR, Gallagher JS, Stephenson RL, Bernstein IL. Pulmonary and immunologic evaluation of foundry workers exposed to methylene diphenyldiisocyanate (MDI). J Allergy Clin Immunol 1988; 82: 55-61.

104. Harris MG, Burge PS, Samson M, Taylor AJ, Pepys J. Isocyanate asthma: respiratory symptoms due to 1,5 naphthylene diisocyanate. Thorax 1979; 34: 762-766.

105. Clarke CW, Aldons PM. Isophorone diisocyanateinduced respiratory disease (IPDI). Aust NZ J Med 1981; 11: 290-292.

106. Vandenplas O, Cartier A, Lesage J, Perrault G, Grammer LC, Malo JL. Occupational asthma caused by a prepolymer but not the monomer of toluene diisocyanate (TDI). J Allergy Clin Immunol 1992; 89: 1183-1188.

107. Vandenplas O, Cartier A, Lesage J, et al. Prepolymers of hexamethylene diisocyanate (HDI) as a cause of occupational asthma. J Allergy Clin Immunol 1993; 91: 850-861.

108. Séguin P, Allard A, Cartier A, Malo JL. Prevalence of occupational asthma in spray painters exposed to several types of isocyanates, including polymethylene polyphenylisocyanates. J Occup Med 1987; 29: 340-344.

109. O'Brien IM, Harries MG, Burge PS, Pepys J. Toluene diisocyanate-induced asthma. I. Reactions to TDI, MDI, HDI and histamine. Clin Allergy 1979; 9: 1-6.

110. Baur X, Dewair M, Fruhmann G. Detection of immunologically sensitized isocyanate workers by RAST and intracutaneous skin tests. J Allergy Clin Immunol 1984; 73: 610-618.

111. Cartier A, Grammer L, Malo JL, et al. Specific serum antibodies against isocyanates: association with occupational asthma. J Allergy Clin Immunol 1989; 84: 507514.

112. Pezzini A, Riviera A, Paggiaro $\mathrm{P}$, et al. Specific IgE antibodies in twenty eight workers with diisocyanateinduced bronchial asthma. Clin Allergy 1984; 14: 453-461.

113. Maccia CA, Bernstein IL, Emmett EA, Brooks SM. In vitro demonstration of specific $\operatorname{IgE}$ in phthalic anhydride hypersensitivity. Am Rev Respir Dis 1976; 113: 701-704.

114. Fawcett IW, Newman-Taylor AJ, Pepys J. Asthma due to inhaled chemical agents: epoxy resin systems containing phthalic acid anhydride, trimellitic acid anhydride and triethylene tetramine. Clin Allergy 1977; 7: 1-14.

115. Wernfors M, Nielsen J, Schütz A, Skerfving S. Phthalic anhydride-induced occupational asthma. Int Arch Allergy Appl Immunol 1986; 79: 77-82.

116. Nielsen J, Welinder H, Schütz A, Skerfving S. Specific 
serum antibodies against phthalic anhydride in occupationally exposed subjects. J Allergy Clin Immunol 1988; 82: $126-133$.

117. Zeiss CR, Patterson R, Pruzansky JJ, Miller MM, Rosenberg M, Levitz D. Trimellitic anhydride-induced airway syndromes: clinical and immunologic studies. J Allergy Clin Immunol 1977; 60: 96-103.

118. Schlueter DP, Banaszak EF, Fink JN, Barboriak J. Occupational asthma due to tetrachlorophthalic anhydride. J Occup Med 1978; 20: 183-187.

119. Howe W, Venables KM, Topping MD, et al. Tetrachlorophthalic anhydride asthma: evidence for specific $\mathrm{IgE}$ antibody. J Allergy Clin Immunol 1983; 71: 5-11.

120. Meadway J. Asthma and atopy in workers with an epoxy adhesive. Br J Dis Chest 1980; 74: 149-154.

121. Nielsen J, Welinder H, Skerfving S. Allergic airway disease caused by methyl tetrahydrophthalic anhydride in epoxy resin. Scand J Work Environ Health 1989; 15: 154-155.

122. Chee CBE, Lee HS, Cheong TH, Wang YT. Occupational asthma due to hexahydrophthalic anhydride: a case report. Br J Ind 1991; 48: 643-645.

123. Rosenman KD, Bernstein DI, O'Leary K, Gallagher JS, D'Souza L, Bernstein IL. Occupational asthma caused by himic anhydride. Scand J Work Environ Health 1987; 13: $150-154$.

124. Gelfand HH. Respiratory allergy due to chemical compounds encountered in the rubber, lacquer, shellac, and beauty culture industries. J Allergy 1963; 34: 374-381.

125. Lam S, Chan-Yeung M. Ethylenediamine-induced asthma. Am Rev Respir Dis 1980; 121: 151-155.

126. Aleva RM, Aalbers R, Koëter GH, de Monchy JGR. Occupational asthma caused by a hardener containing an aliphatic and cycloliphatic diamine. Am Rev Respir Dis 1992; 145: 1217-1218.

127. Pepys J, Pickering CAC. Asthma due to inhaled chemical fumes: amino-ethyl ethanolamine in aluminium soldering flux. Clin Allergy 1972; 2: 197-204.

128. Sterling GM. Asthma due to aluminium soldering flux. Thorax 1967; 22: 533-537.

129. Vallières M, Cockcroft DW, Taylor DM, Dolovich J, Hargreave FE. Dimethyl ethanolamine-induced asthma. Am Rev Respir Dis 1977; 115: 867-871.

130. Sargent EV, Mitchell CA, Brubaker RE. Respiratory effects of occupational exposure to an epoxy resin system. Arch Environ Health 1976; 31: 236-240.

131. Pepys J, Pickering CAC, Loudon HWG. Asthma due to inhaled chemical agents: piperazine dihydrochloride. Clin Allergy 1972; 2: 189-196.

132. Hagmar L, Bellander T, Bergöö B, Simonsson BG. Piperazine-induced occupational asthma. J Occup Med 1982; 24: 193-197.

133. Welinder H, Hagmar L, Gustavsson C. IgE antibodies against piperazine and $\mathrm{N}$-methyl-piperazine in two asthmatic subjects. Int Arch Allergy Appl Immunol 1986; 79: 259-262.

134. Belin L, Wass U, Audunsson G, Mathiasson L. Amines: possible causative agents in the development of bronchial hyperreactivity in workers manufacturing polyurethanes from isocyanates. $\mathrm{Br} J$ Ind Med 1983; 40: 251-257.

135. Silberman DE, Sorrell AH. Allergy in fur workers with special reference to paraphenylenediamine. J Allergy 1959; 30: 11-18.

136. Lamboum EM, Hayes JP, McAllister WA, NewmanTaylor AJ. Occupational asthma due to EPO 60. Br J Ind Med 1992; 49: 294-295.

137. Burge PS, Harries MG, O'Brien I, Pepys J. Bronchial provocation studies in workers exposed to the fumes of electronic soldering fluxes. Clin Allergy 1980; 10: $137-$ 149.

138. Burge PS, Edge G, Hawkins R, White V, Taylor AN. Occupational asthma in a factory making flux-cored solder containing colophony. Thorax 1981; 36: 828-834.

139. Weir DC, Robertson AS, Jones S, Burge PS. Occupational asthma due to soft corrosive soldering fluxes containing zinc chloride and ammonium chloride. Thorax 1989; 44: 220-223.

140. Stevens JJ. Asthma due to soldering flux: a polyether alcohol-polypropylene glycol mixture. Ann Allergy 1976; 36: 419-422.

141. Milne J, Gandevia B. Occupational asthma and rhinitis due to western (Canadian) red cedar. Med J Aust 1969; 2: 741-744.

142. Ishizaki T, Sluda T, Miyamoto T, Matsumara Y, Mizuno $\mathrm{K}$, Tomaru M. Occupational asthma from western red cedar dust (Thuja plicata) in furniture factory workers. J Occup Med 1973; 15: 580-585.

143. Chan-Yeung M, Barton GM, Maclean L, Grzybowski S. Occupational asthma and rhinitis due to western red cedar (Thuja plicata). Am Rev Respir Dis 1973; 108: 10941102.

144. Chan-Yeung M, Lam S, Koener S. Clinical features and natural history of occupational asthma due to western red cedar (Thuja plicata). Am J Med 1982; 72: 411-415.

145. Chan-Yeung M, Vedal S, Kus J, Maclean L, Enarson D, Tse KS. Symptoms, pulmonary function, and bronchial hyperreactivity in western red cedar workers compared with those in office workers. Am Rev Respir Dis 1984; 130: 1038-1041.

146. Chan-Yeung M, Abboud R. Occupational asthma due to California redwood (Sequoia sempervirens) dusts. Am Rev Respir Dis 1976; 114: 1027-1031.

147. doPico GA. Asthma due to dust from redwood (Sequoia sempervirens). Chest 1978; 73: 424-425.

148. Greenberg M. Respiratory symptoms following brief exposure to cedar of Lebanon (Cedra libani) dust. Clin Allergy 1972; 2: 219-224.

149. Eaton KK. Respiratory allergy to exotic wood dust. Clin Allergy 1973; 3: 307-310.

150. Pickering CAC, Batten JC, Pepys J. Asthma due to inhaled wood dusts - western red cedar and iroko. Clin Allergy 1972; 2: 213-218.

151. Azofra J, Olaguibel JM. Occupational asthma caused by iroko wood. Allergy 1989; 44: 156-158.

152. Sosman AJ, Schlueter DP, Fink JN, Barboriak JJ. Hypersensitivity to wood dust. N Engl J Med 1969; 281: 977-980.

153. Booth BH, Lefoldt RH, Moffitt EM. Hypersensitivity to wood dust. J Allergy Clin Immunol 1976; 57: 352-357.

154. Hinojosa M, Moneo I, Dominguez J, Delgado E, Losada E, Alcover R. Asthma caused by African maple (Triplochiton scleroxylon) wood dust. J Allergy Clin Immunol 1984; 74: 782-786.

155. Paggiaro PL, Cantalupi R, Filieri M, et al. Bronchial asthma due to inhaled wood dust: Tanganyika aningre. Clin Allergy 1981; 11: 605-610.

156. Bush RK, Clayton D. Asthma due to central american walnut (Juglans olanchana) dust. Clin Allergy 1983; 13: 389-394.

157. Ordman D. Wood dust as an inhalant allergen. Bronchial asthma caused by kejaat wood (Pterocarpus angolensis). S Afr Med 1949; 23: 973-975.

158. Bush RK, Yunginger JW, Reed CE. Asthma due to 
African zebrawood (Microberlinia) dust. Am Rev Respir Dis 1978; 117: 601-603.

159. Hinojosa M, Losada E, Moneo I, Dominguez J, Carrillo T, Sanchez-Cano M. Occupational asthma caused by African maple (Obeche) and Ramin: evidence of crossreactivity between these two woods. Clin Allergy 1986; 16: 145-153.

160. Raghuprasad PK, Brooks SM, Litwin A, Edwards JJ, Bernstein IL, Gallagher J. Quillaja bark (soapbark)induced asthma. J Allergy Clin Immunol 1980; 65: 285-287.

161. Hausen BM, Herrmann B. Bow-makers disease: an occupational disease in the manufacture of wooden bows for string instruments. Dtsch Med Wochenschr 1990; 115 : 169-173.

162. Malo JL, Cartier A. Occupational asthma caused by exposure to ash wood dust (Fraxinus americana). Eur Respir J 1989; 2: 385-387.

163. Basomba A, Burches E, Almodovar A, Rojas D, Hernandez $\mathrm{F}$ de. Occupational rhinitis and asthma caused by inhalation of Balfourodendron riedelianum (Pau Marfim) wood dust. Allergy 1991; 46: 316-318.

164. Innocenti A, Romeo R, Mariano A. Asthma and systemic toxic reaction due to cabreuva (Myrocarpus fastigiatus Fr. All.) wood dust. Med Lav 1991; 82: 446-450.

165. Cartier A, Chan H, Malo JL, Pineau L, Tse KS, ChanYeung M. Occupational asthma caused by Eastern white cedar (Thuya occidentalis) with demonstration that plicatic acid is present in this wood dust and is the causal agent. J Allergy Clin Immunol 1986; 77: 639-645.

166. Maestrelli P, Marcer G, Dal Vecchio L. Occupational asthma due to ebony wood (Diospyros crassiflora) dust. Ann Allergy 1987; 59: 347-349.

167. Reques FG, Fernandez RP. Asthme professionnel à un bois exotique. Nesorgordonia papaverifera (danta ou kotibe). Rev Mal Respir 1988; 5: 71-73.

168. Uragoda CG. Asthma and other symptoms in cinnamon workers. Br J Ind Med 1984; 41: 224-227.

169. Malo JL, Cartier A, Boulet LP. Occupational asthma in sawmills of Eastern Canada and United States. J Allergy Clin Immunol 1986; 78: 392-398.

170. Pepys J, Pickering CAC, Hughes EG. Asthma due to inhaled chemical agents: complex salts of platinum. Clin Allergy 1972; 2: 391-396.

171. Brooks SM, Baker DB, Gann PH, et al. Cold air challenge and platinum skin reactivity in platinum refinery workers. Chest 1990; 97: 1401-1407.

172. McConnell LH, Fink JN, Schlueter DP, Schmidt MG. Asthma caused by nickel sensitivity. Ann Intern Med 1973; 78: 888-890.

173. Block GT, Yeung M. Asthma induced by nickel. $J$ Am Med Assoc 1982; 247: 1600-1602.

174. Malo JL, Cartier A, Doepner M, Nieboer E, Evans S, Dolovich J. Occupational asthma caused by nickel sulfate. J Allergy Clin Immunol 1982; 69: 55-59.

175. Hartmann AL, Walter H, Wuthrich B. Allergisches berufsasthma auf pektinase, ein pektolytisches enzym. Schweiz Med Wschr 1983; 113: 265-267.

176. Gheysens B, Auxwerx J, Van Den Eeckhout A, Demedts M. Cobalt-induced bronchial asthma in diamond polishers. Chest 1985; 88: 740-744.

177. Malo JL, Cartier A. Occupational asthma due to fumes of galvanized metal. Chest 1987; 92: 375-377.

178. Vogelmeier C, König G, Bencze K, Fruhmann G. Pulmonary involvement in zinc fume fever. Chest 1987 ; 92: 946-949.

179. Bruckner HC. Extrinsic asthma in a tungsten carbide worker. J Occup Med 1967; 9: 518-519.
180. Smith AR. Chrome poisoning with manifestations of sensitization. J Am Med Assoc 1931; 94: 95-98.

181. Joules H. Asthma from sensitization to chromium. Lancet 1932; ii: 182-183.

182. Keskinen G, Kalliomaki PL, Alanko K. Occupational asthma due to stainless steel welding fumes. Clin Allergy 1980; 10: 151-159.

183. Novey HS, Habib M, Wells ID. Asthma and IgE antibodies induced by chromium and nickel salts. J Allergy Clin Immunol 1983; 72: 407-412.

184. Shirakawa T, Kusaka Y, Fujimura N, Kato M, Heki S, Morimoto K. Hard metal asthma: cross immunological and respiratory reactivity between cobalt and nickel. Thorax 1990; 45: 267-271.

185. Davies RJ, Hendrick DJ, Pepys J. Asthma due to inhaled chemical agents: ampicillin, benzyl penicillin, 6-amino penicillanic acid and related substances. Clin Allergy 1974; 4: 227-247.

186. Lagier F, Cartier A, Dolovich J, Malo J-L. Occupational asthma in a pharmaceutical worker exposed to penicillamine. Thorax 1989; 44: 157-158.

187. Coutts II, Dally MB, Newman-Taylor AJ, Pickering CAC, Horsfield N. Asthma in workers manufacturing cephalosporins. $\mathrm{Br}$ Med J 1981; 283: 950.

188. Briatico-Vangosa G, Beretta F, Bianchi S, et al. Bronchial asthma due to 7-aminocephalosporanic acid (7-ACA) in workers employed in cephalosporin production. Med Lav 1981; 72: 488-493.

189. Kammermeyer JK, Mathews KP. Hypersensitivity to phenylglycine acid chloride. J Allergy Clin Immunol 1973; 52: 73-84.

190. Busse WW, Schoenwetter WF. Asthma from psyllium in laxative manufacture. Ann Intern Med 1975; 83: 361-362.

191. Bardy JD, Malo JL, Séguin P, et al. Occupational asthma and IgE sensitization in a pharmaceutical company processing psyllium. Am Rev Respir Dis 1987; 135: 1033-1038.

192. Cartier A, Malo J-L, Dolovich J. Occupational asthma in nurses handling psyllium. Clin Allergy 1987; 17: 1-6.

193. Malo JL, Cartier A, L'Archevêque J, et al. Prevalence of occupational asthma and immunologic sensitization to psyllium among health personnel in chronic care hospitals. Am Rev Respir Dis 1990; 142: 1359-1366.

194. Harries MG, Newman-Taylor AJ, Wooden J, MacAuslan A. Bronchial asthma due to alpha-methyldopa. $\mathrm{Br} \mathrm{Med}$ $J$ 1979; 1 (6176): 1461.

195. Davies RJ, Pepys J. Asthma due to inhaled chemical agents: the macrolide antibiotic spiramycin. Clin Allergy 1975; 1: 99-107.

196. Malo JL, Cartier A. Occupational asthma in workers of a pharmaceutical company processing spiramycin. Thorax 1988; 43: 371-377.

197. Moscato G, Naldi L, Candura F. Bronchial asthma due to spiramycin and adipic acid. Clin Allergy 1984; 14 : 355-361.

198. Fawcett IW, Pepys J, Erooga MA. Asthma due to "glycyl compound" powder: an intermediate in production of salbutamol. Clin Allergy 1976; 6: 405-409.

199. Greene SA, Freedman S. Asthma due to inhaled chemical agents: amprolium hydrochloride. Clin Allergy 1976; $6: 105-108$.

200. Fawcett IW, Pepys J. Allergy to a tetracycline preparation. Clin Allergy 1976; 6: 301-303.

201. Menon MPS, Das AK. Tetracycline asthma: a case report. Clin Allergy 1977; 7: 285-290.

202. Asai S, Shimoda T, Hara K, Fujiwara K. Occupational 
asthma caused by isonicotinic acid hydrazide (INH) inhalation. J Allergy Clin Immunol 1987; 80: 578-582.

203. Perrin B, Malo JL, Cartier A, Evans S, Dolovich J. Occupational asthma in a pharmaceutical worker exposed to hydralazine. Thorax 1990; 45: 980-981.

204. Lee HS, Wang YT, Yeo CT, Tan KT, Ratnam KV. Occupational asthma due to tylosin tartrate. Br J Ind Med 1989; 46: 498-499.

205. Luczynska CM, Marshall PE, Scarisbrick DA, Topping MD. Occupational allergy due to inhalation of ipecacuanha dust. Clin Allergy 1984; 14: 169-175.

206. Coutts II, Lozewicz S, Dally MB, et al. Respiratory symptoms related to work in a factory manufacturing cimetidine tablets. $\mathrm{Br}$ Med $J$ 1984; 288: 14-18.

207. Biagini RE, Bernstein DM, Klincewicz SL, Mittman R, Bernstein IL, Henningsen GM. Evaluation of cutaneous responses and lung function from exposure to opiate compounds among ethical narcotics-manufacturing workers. J Allergy Clin Immunol 1992; 89: 108-117.

208. Feinberg SM, Watrous RM. Atopy to simple chemical compounds: sulfonechloramides. J Allergy 1945; 16: 209-220.

209. Bourne MS, Flindt MLH, Walker JM. Asthma due to industrial use of chloramine. Br Med J 1979; 2 :10-12.

210. Dijkman JG, Vooren PH, Kramps JA. Occupational asthma due to inhalation of chloramine-T. 1. Clinical observations and inhalation-provocation studies. Int Arch Allergy Appl Immunol 1981; 64: 422-427.

211. Andrasch RH, Bardana EJ, Koster F, Pirofsky B. Clinical and bronchial provocation studies in patients with meatwrapper's asthma. J Allergy Clin Immunol 1976; 58: 291-298.

212. Sokol WN, Aelony Y, Beall GN. Meat-wrapper's asthma. A new syndrome? J Am Med Assoc 1973; 226: 639-641.

213. Lee HS, Yap J, Wang YT, Lee CS, Tan KT, Poh SC. Occupational asthma due to unheated polyvinylchloride resin dust. Br J Ind Med 1989; 46: 820-822.

214. Kopp SK, McKay RT, Moller DR, Cassedy K, Brooks SM. Asthma and rhinitis due to ethylcyanoacrylate instant glue. Ann Intern Med 1985; 102: 613-615.

215. Weiner A. Bronchial asthma due to the organic phosphate insecticides. Ann Allergy 1961; 19: 397-401.

216. Alanko K, Keskinen H, Byorksten F, Ojanen S. Immediatetype hypersensitivity to reactive dyes. Clin Allergy 1978; 8: 25-31.

217. Park HS, Lee MK, Kim BO, et al. Clinical and immunologic evaluations of reactive dye-exposed workers. $J$ Allergy Clin Immunol 1991; 87: 639-649.

218. Romano C, Sulotto F, Pavan I, Chiesa A, Scansetti G. A new case of occupational asthma from reactive dyes with severe anaphylactic response to the specific challenge. Am J Ind Med 1992; 21: 209-216.

219. Pepys J, Hutchcroft BJ, Breslin ABX. Asthma due to inhaled chemical agents-persulphate salts and henna in hairdressers. Clin Allergy 1976; 6: 399-404.

220. Baur X, Fruhmann G, Liebe VV. Occupational asthma and dermatitis after exposure to dusts of persulfate salts in two industrial workers. Respiration 1979; 38: 144-150.

221. Blainey AD, Ollier S, Cundell D, Smith RE, Davies RJ. Occupational asthma in a hairdressing salon. Thorax 1986; 41: 42-50.

222. Pankow W, Hein H, Bittner K, v Wichert P. Asthma in hairdressers induced by persulphate. Pneumologie 1989; 43: 173-175.

223. Gamboa PM, de la Cuesta CG, Garcia BE, Castillo JG, Oehling A. Late asthmatic reaction in a hairdresser, due to the inhalation of ammonium persulphate salts. Allergol Immunopathol 1989; 17: 109-111.

224. Slovak AJM. Occupational asthma caused by a plastics blowing agent, azodicarbonamide. Thorax 1981; 36 906-909.

225. Malo JL, Pineau L, Cartier A. Occupational asthma due to azobisformamide. Clin Allergy 1985; 15: 261-264.

226. Normand J-C, Grange F, Hernandez C, et al. Occupational asthma after exposure to azodicarbonamide: report of four cases. Br J Ind Med 1989; 46: 60-62.

227. Graham V, Coe MJS, Davies RJ. Occupational asthma after exposure to a diazonium salt. Thorax 1981; 36: 950-951.

228. Luczynska CM, Hutchcroft BJ, Harrison MA, Dornan JD, Topping MD. Occupational asthma and specific $\mathrm{IgE}$ to diazonium salt intermediate used in the polymer industry. J Allergy Clin Immunol 1990; 85: 1076-1082.

229. Nagy L, Orosz M. Occupational asthma due to hexachlorophene. Thorax 1984; 39: 630-631.

230. Hendrick DJ, Lane DJ. Formalin asthma in hospital staff. Br Med J 1975; 1: 607-608.

231. Burge PS, Harries MG, Lam WK, O'Brien IM, Patchett PA. Occupational asthma due to formaldehyde. Thorax 1985; 40: 255-260.

232. Nordman H, Keskinen H, Tuppurainen M. Formaldehyde asthma: rare or overlooked? J Allergy Clin Immunol 1985; 75: 91-99.

233. Cockcroft DW, Hoeppner VH, Dolovich J. Occupational asthma caused by cedar urea formaldehyde particle board. Chest 1982; 82: 49-53.

234. Frigas E, Filley WV, Reed CE. Asthma induced by dust from urea-formaldehyde foam insulating material. Chest 1981; 79: 706-707.

235. Malo JL, Gagnon G, Cartier A. Occupational asthma due to heated freon. Thorax 1984; 39: 628-629.

236. Cockcroft DW, Cartier A, Jones G, Tarlo SM, Dolovich J, Hargreave FE. Asthma caused by occupational exposure to a furan-based binder system. I Allergy Clin Immunol 1980; 66: 458-463.

237. Topping MD, Forster HW, Ide CW, Kennedy FM, Leach AM, Sorkin S. Respiratory allergy and specific immunoglobin $\mathrm{E}$ and immunoglobin $\mathrm{G}$ antibodies to reactive dyes used in the wool industry. J Occup Med 1989; 31: 857862.

238. Moscato G, Biscaldi G, Cottica D, Pugliese F, Candura S, Candura F. Occupational asthma due to styrene: two case reports. J Occup Med 1987; 29: 957-960.

239. Jachuck SJ, Bound CL, Steel J, Blain PG. Occupational hazard in hospital staff exposed to 2 percent glutaraldehyde in an endoscopy unit. J Soc Occup Med 1989; 39: 69-71.

240. Lozewicz S, Davison AG, Hopkirk A, et al. Occupational asthma due to methyl methacrylate and cyanoacrylates. Thorax 1985; 40: 836-839.

241. Pickering CAC, Bainbridge D, Birtwistle IH, Griffiths DL. Occupational asthma due to methyl methacrylate in an orthopaedic theatre sister. Br Med J 1986; 292: 1362-1363.

242. Hendrick DJ, Connolly MJ, Stenton SC, Bird AG, Winterton IS, Walters EH. Occupational asthma due to sodium isononanoyl oxybenzene sulphonate, a newly developed detergent ingredient. Thorax 1988; 43: 501-502.

243. Waclawski ER, McAlpine LG, Thomson NC. Occupational asthma in nurses caused by Chlorhexidine and alcohol aerosols. Br Med J 1989; 298: 929-930.

244. Burge PS. Occupational asthma, rhinitis and alveolitis due to colophony. Clin Immunol Allergy 1984; 4: 55-82. 
245. Dugue P, Faraut C, Figueredo M, Bettendorf A, Salvadori JM. Asthme professionnel à l'oxyde d'éthylène chez une infirmière. Presse Méd 1991; 20: 1455.

246. Gannon PFG, Sherwood-Burge P, Benfield CFA. Occupational asthma due to polyethylene shrink wrapping (paper wrappers asthma). Thorax 1992; 47: 759.

247. Honda I, Kohrogi H, Ando M, et al. Occupational asthma induced by the fungicide tetrachloroisophthalonitrile. Thorax 1992; 47: 760-761.

248. Shelton D, Urch B, Tarlo SM. Occupational asthma induced by a carpet fungicide, tributyl tin oxide. J Allergy Clin Immunol 1992; 90: 274-275.

249. Tarlo SM. Occupational asthma induced by tall oil in the rubber tyre industry. Clin Exp Allergy 1991; 22: 99-102.

250. Kennes B, Garcia-Herreros P, Sierckx P. Asthma from plexiglas powders. Clin Allergy 1981; 11: 49-54.

251. Tarlo SM, Wong L, Roos J, Booth N. Occupational asthma caused by latex in a surgical glove manufacturing plant. J Allergy Clin Immunol 1990; 85: 626-631.
252. Kern DG, Frumkin H. Asthma in respiratory therapists. Ann Intern Med 1989; 110: 767-773.

253. Musk AW, Peach S, Ryan G. Occupational asthma in a mineral analysis laboratory. $B r J$ Ind Med 1988; 45: 381-386.

254. Hendy MS, Beattie BE, Burge PS. Occupational asthma due to an emulsified oil mist. Br J Ind Med 1985; 42: 51-54.

255. Midttun O. Bronchial asthma in the aluminium industry. Acta Allergol 1960; 15: 208-221.

256. Saric M, Godnic-Cvar J, Gonzi M, Stilinovic L. The role of atopy in potroom workers' asthma. Am J Ind Med 1986; 9: 239-242.

257. Wergeland E, Lund E, Waage JE. Respiratory dysfunction after potroom asthma. Am J Ind Med 1987; 11: 627-636.

258. O'Donnell TV, Welford B, Coleman ED. Potroom asthma: New Zealand experience and follow-up. Am J Ind Med 1989; 14: 43-49. 